\title{
A comparative examination of healthcare use related to hearing impairment in Europe
}

Global \& Regional Health Technology Assessment

2018, Vol. 2018: I-22

(C) The Author(s) 2018

Reprints and permissions: sagepub.co.uk/journalsPermissions.nav DOI: | 0.1 | 777/22842403।8757938 journals.sagepub.com/home/grh

(S)AGE

\author{
Mimi Xiao' and Ciaran O'Neill ${ }^{2}$
}

\begin{abstract}
Introduction: The economic burden of hearing impairment is an area of increased interest. In this paper we examine the relationship between hearing impairment and service use in 14 European countries.

Methods: Based on the Survey of Health Ageing and Retirement in Europe (SHARE) undertaken in 2013, Poisson regression models are used to analyse the relationship between the number of visits/number of nights in hospital, and hearing impairment controlling for a number of covariates.

Results: We find that hearing impairment is generally associated with increased use of primary and secondary healthcare services when other aspects of health have been controlled. Comparative analysis revealed that where access to hearing assistive technology was greatest the additional use of services was least.

Conclusions: The comparative analysis suggests that variations exist across countries in respect of the additional healthcare use occasioned by hearing impairment. They may also provide valuable insights into how the burden of illness might be reduced.
\end{abstract}

\section{Keywords}

Hearing impairment, Service use, Primary care, Secondary care

Accepted: November 24, 2017

\section{Introduction}

Impaired health resulting from whatever source presents challenges to individuals and societies. These challenges can be presented in terms of an economic burden - costs and disutilities - that arise from the experience of and efforts to manage or resolve the health issue. Examining this burden can help us understand the magnitude and distribution of the burden within society, how it might impact different agents, and what impact particular resource allocation decisions might have on these. An examination of the burden associated with impaired health can throw into sharp relief the interconnectedness of different budgets, for example, and how attempts to effect savings in one area can have unintended and potentially greater consequences in others.

The study of economic burden has become increasingly popular in the health and health economics literatures. Figure 1, for example, shows the trend over time in the number of academic papers located using a popular search engine in health sciences (PubMed) using the search term "economic burden." As shown, the number has risen almost exponentially over time. In part, their popularity reflects the insights they can afford into issues of cost, disutility, and the distribution of these within society. In part, too, their popularity reflects their usefulness in drawing attention to specific conditions/diseases among policy makers, with a view to increasing the priority afforded them in resource allocation decisions. As healthcare budgets have come under increasing pressure and competition for resources increases, so too has the importance of -garnering the attention of

\footnotetext{
ISchool of Business and Economics, National University of Ireland, Galway, Ireland

${ }^{2}$ Centre for Public Health, Queens University Belfast, Northern Ireland, UK

Corresponding author:

Mimi Xiao, Institute for Lifecourse and Society, NUI Galway, University Road, Galway, Ireland.

Email: mimi.xiao@nuigalway.ie
} 


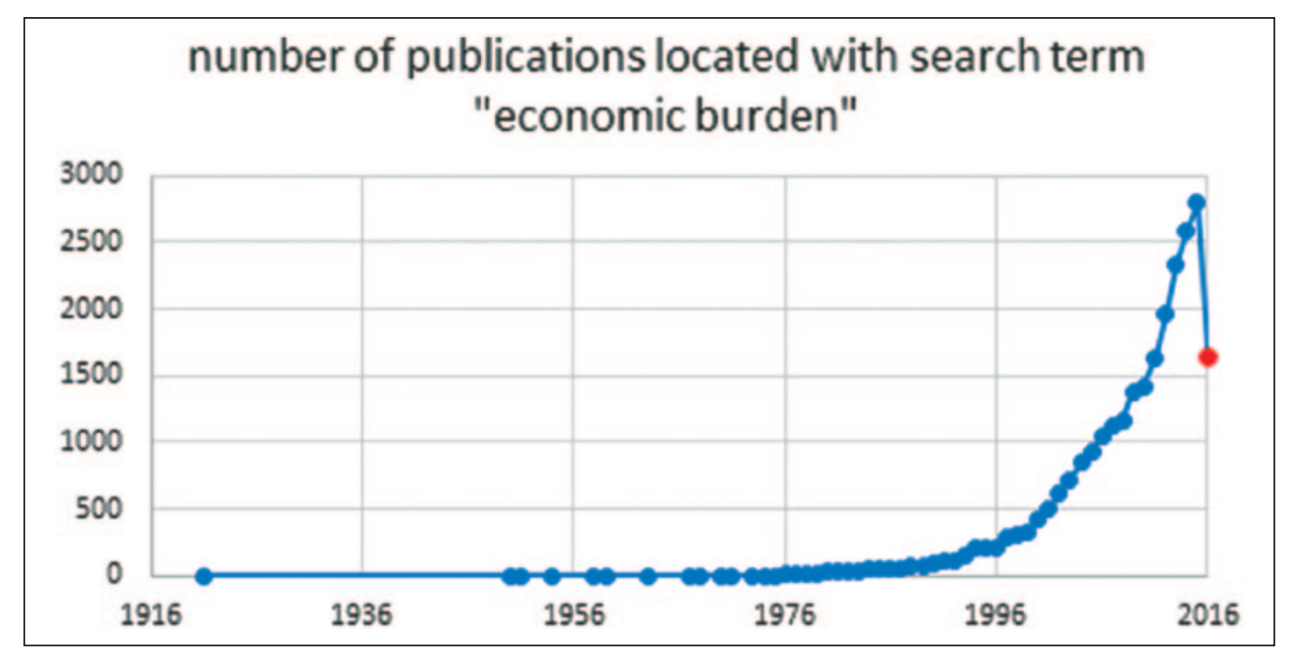

Fig. I. The blue line represents the trend over time in the number of academic papers located using a popular search engine in health sciences (PubMed) using the search term "economic burden."

policy makers; it is perhaps unsurprising, therefore, that efforts to gain their attention using such studies has also increased.

Economic burden can be broken down into 2 parts: (i) a financial element - sometimes referred to as cost-of-illness; and (ii) a nonfinancial element. The latter refers to the disutility associated with lost health-related quality and quantity of life occasioned by a condition. It is possible in principle to monetise such disutility. Preference elicitation techniques, such as contingent valuation and discrete choice experimentation, plus revealed preference techniques, such as hedonic pricing and travel cost analyses, offer methods by which this may be achieved. Alternatively, thresholds used in health technology assessment - notionally reflective of societal willingness to pay for a given amount of health, such as a quality adjusted life year - can be used for this, adopting what is sometimes referred to as a net monetary benefit approach to the valuation of disutility. However, such approaches tend to be rarely used in burden of illness studies; disutility is more readily reflected and understood with reference to measures of morbidity and mortality associated with a specific condition.

Financial costs can also be separated into 2 parts: (i) those related to use of services: health, social and personal services associated with treatment/management of the condition; and (ii) non-healthcare-related costs associated with, for example, lost production arising from absenteeism, early retirement, and premature death, which may arise as a result of the condition. Within publicly funded healthcare systems, there is an understandable focus on the financial burden that the condition's management typically generates for services and, in particular, those for which state agencies are responsible either for funding or providing. It is clear that a condition can have significant financial costs; for example, among unpaid carers or in budgets not directly related to health, such as -education (1-4).
The economic burden of hearing impairment is a -relatively neglected area of research. While a large body of research has examined the association between hearing impairment, falls (22), mental health, mortality, and cognition, compared to many diseases relatively few studies have examined the economic burden associated with hearing impairment from a societal perspective $(14,3)$ and a smaller number of these studies have been subject to peer review (5-8). A few studies have examined aspects of economic burden related to hearing impairment, though these have tended to be confined to particular population subgroups defined, for example, by age (9) or role-specific causes, such as disease (10) or noise (11). The difficulty with such approaches is that either important aspects of economic burden may be omitted because they are not relevant to the population studied; or, in focusing on the role of specific causes, they ignore large sections of society that may experience impairment but not as a result of these causes.

Only 4 studies that we are aware of have examined the relationships between service use and hearing impairment $(12,8,5,6)$. The broad consensus among these is that hearing impairment is associated with additional healthcare expenditures. Foley et al (13), for example, estimate for those aged 65 and over the additional healthcare costs are roughly $\$ 392$ per person (2012 prices). Among these - those that allowed a comparison with other aspects of burden $(8,12,15)$ whose analyses adopted a lifetime approach to costs - it is clear that direct medical costs are modest relative to other aspects of disease burden. Both Mohr et al (11) and Honeycutt et al (13), for example, suggest that approximately $70 \%$ of costs are related to productivity losses, roughly $7 \%$ (8) being related to direct medical expenditure. A more recent study estimated the economic burden related to disutility associated with hearing impairment in France using epidemiological data, the impact of hearing impair- 
ment on quality of life, and the notional value of a willingness for pay for health-related quality of life (14).

To the best of our knowledge, no comparative analyses of the economic burden of hearing impairment as it is experienced in different countries have been undertaken using the same methodology. In this paper we have built on work undertaken by O'Neill et al (3), which examined the association between hearing impairment and healthcare use in the UK. We examined the association between healthcare use and hearing impairment in 14 European countries; we compared countries in terms of the additional service use related to hearing impairment and relative to other commonly reported health conditions.

\section{Methods}

Data were extracted from the most recent wave of the Survey of Health Ageing and Retirement in Europe (SHARE) undertaken in 2013. In brief, this is a survey on the physical and psychological health, socio-economic status, demographic characteristics, and social and family networks -support of about 123,000 individuals aged 50 and over and their partners. The survey was undertaken in a number of -European and surrounding countries; in 2013 these comprised Austria, Germany, Sweden, the Netherlands, France, Spain, Denmark, Italy, Switzerland, Estonia, Luxembourg, Belgium, the Czech Republic, Slovenia, and Israel. Further details of the survey, the sampling approach, the response rates, and the questionnaires are available from SHARE (24). Aspects of the survey are panel in nature and linked in terms of timing and scope with similar surveys undertaken in the USA, PR China, England, Japan, Brazil, and South Korea.

Data extracted for analysis included details of each respondent's age, gender, education, marital status, country of residence, use of healthcare services, and health status. Health status was captured in a series of conditions/ events the individual is asked if they had experienced. In total, 16 conditions were identified explicitly, including diabetes, hypertension, stroke, heart attack, cancer, epilepsy, emotional problems (including anxiety and depression). A full list is presented in Table I. In addition, individuals were asked if they experienced problems with near or far vision and (separately) if they experienced hearing impairment.

Use of health services related to primary and secondary care were also gathered. The specific questions asked are detailed in Appendix 1. In respect of both primary and secondary care, the interval to which use relates is the previous 12 months. In respect of primary care, the question does not permit the identification of, for example, visits to the -General Practitioner's office as opposed to consultations with a -Practice Nurse or telephone consultations, but rather simply the total number of consultations. In respect of secondary care, the survey question (also reported in Appendix
Table I. Medical conditions of the respondents that had been diagnosed by doctors.

\section{Condition}

A heart attack, including myocardial infarction, coronary thrombosis, or any other heart problem including congestive heart failure

High blood pressure or hypertension

High blood cholesterol

A stroke or cerebral vascular disease

Diabetes or high blood sugar

Chronic lung disease, such as chronic bronchitis or emphysema Cancer or malignant tumour, including leukaemia or lymphoma, but excluding minor skin cancers

Stomach or duodenal ulcer, peptic ulcer

Parkinson disease

Cataracts

Hip fracture

Other fractures

Alzheimer disease, dementia, organic brain syndrome, senility or any other serious memory impairment

Other affective or emotional disorders, including anxiety, nervous or psychiatric problems

Rheumatoid arthritis

Osteoarthritis, or other rheumatism

Other

1) identified the number of nights spent in hospital; no data on outpatient or day-case use were available.

Poisson regression models were used to analyse the relationship between the number of visits/number of nights in hospital and hearing impairment controlling for a number of covariates. The Poisson model was chosen because of its usefulness in analysing count data. Covariates controlled for were a dummy variable for each of the other conditions the individual reported having ( 1 if present; 0 otherwise) age (in years) and age squared to allow for nonlinear relationships, gender ( 1 if male; 0 otherwise), marital status (married or living together as such, separated/ divorced, never married, or widowed in each case as a dummy variable equal to 1 or 0 as relevant), and years of education. Separate models were estimated for primary and secondary care use in respect of each country. The analysis was conducted using STATA14.

Three confirmatory analyses were undertaken. In the first, reported in Appendix 2, comorbid conditions were entered in the model as a count rather than as a set of dummy variables to ascertain if the relationship between hearing impairment and service use remained robust. In the second analysis, IV Poisson models were estimated in which hearing impairment was treated as endogenous with the count of comorbid -conditions. The instruments used to estimate hearing impairment were the extent to which natural teeth had been artificially replaced (totally, partially, or not at all); the age at which the respondent's mother and father died (an 
integer); whether the respondent had been unable to see a doctor in the past 12 months because the waiting time was too long (yes or no); whether the respondent had been unable to see a doctor in the past 12 months because the cost was too high (yes or no); whether the respondent had supplementary health insurance (yes or no); how much the respondent paid for medicines (prescribed and over the counter) in the past 12 months; whether the respondent was born in the country of the survey (yes or no); how good the respondent's self-assessed near vision was (a 5-point Likert scale ranging from excellent, very good, good, fair to poor); and the respondent's gender (male or -female). The variables were selected based on the hypothesis that they captured aspects of need whether met or unmet. Given the additional number of variables required in the analysis, increased issues and instances where there were missing values, functions were estimated in respect of a pooled sample across countries that provided larger samples; specifically Belgium, the Czech Republic, Denmark, Holland, Italy, Germany, Slovenia, Spain, and Sweden. These results are reported in Appendix 5. In the third confirmatory analysis, the original models estimated for each country were reestimated using backwards elimination to identify a reduced set of significant covariates (Appendix 6).

\section{Results}

Summary statistics by country in respect of the sample used in the main regression analyses are detailed in Appendix 2. In a number of instances, data on socio-economic variables (e.g., education, marital status, and in respect of healthcare service use) were poorly reported. Consequently, the usable sample was often quite small. This was seen to particularly affect a number of countries, such as Switzerland and France (e.g., see the sample size for regressions in Tabs. III and Supplementary Table 1). The potential impact of this on the results is discussed below.

In Table II, the correlation between hearing impairment status and a range of conditions included in Table I are shown. Hearing impairment is significantly and positively correlated with many of these conditions, including emotional issues, Alzheimer disease, heart attack, stroke, and hypertension, though the correlation is relatively low in absolute terms. As the data are crosssectional in nature these cannot be interpreted as causative relationships.

In Supplementary Tables 1 and 2 (see Appendix 3) the marginal effects from a series of regression analyses on the use of primary and secondary care services are detailed by country. The marginal effects with respect to hearing impairment are reported separately in -Table III for those countries where the sample size was thought to be sufficient for meaningful analysis. As noted, given the nature of the dependent variables, count models - specifically Poisson models - were used. The marginal effect in these shows the additional number of visits/night that were incurred associated with impaired hearing. In each case, the marginal effect shows the impact on service use of hearing impairment where other variables are held at the -respective sample mean for that country's sample. As shown, with the exception of those countries in which the sample size fell below 300 and Denmark in respect of secondary care, the impact of hearing impairment is uniformly to increase both primary and secondary care use, though the extent to which care use is increased varies between countries. In the first confirmatory analyses reported in Appendix 4, while the magnitude of the marginal effect changes, the sign of estimate and significance of the relationship between hearing impairment and service use is

Table II. Pairwise correlation between self-reported hearing impairment and other conditions.

\begin{tabular}{ll}
\hline Condition & Correlation (significance level) \\
\hline Emotional/mood disorders & $0.05(<0.01)$ \\
Alzheimer disease & $0.10(<0.01)$ \\
Stoke & $0.07(<0.01)$ \\
Hypertension & $0.08(<0.01)$ \\
Heart attack & $0.11(<0.01)$ \\
Cancer & $0.03(<0.01)$
\end{tabular}

$n=65,912$.

Table III. Marginal effects with respect to impaired hearing.

\begin{tabular}{lllcr}
\hline Country & $\begin{array}{l}\text { Marginal effect } \\
\text { for primary care }\end{array}$ & $\begin{array}{l}\text { Confidence } \\
\text { interval 95\% }\end{array}$ & $\begin{array}{l}\text { Marginal effect for } \\
\text { secondary care }\end{array}$ & $\begin{array}{c}\text { Confidence } \\
\text { interval } 95 \%\end{array}$ \\
\hline Belgium & 0.98 & $0.620,10.339$ & 0.61 & $0.450,0.773$ \\
Czech Rep. & 0.83 & $0.483,10.186$ & 0.88 & $0.678,10.085$ \\
Germany & 0.47 & $0.243,0.694$ & $0.899,10.110$ \\
Denmark & 1.25 & $0.966,10.528$ & $-0.596,-0.320$ \\
Spain & 0.36 & $0.172,0.542$ & 0.46 & 0.377 \\
Italy & 0.81 & $0.474,10.139$ & 0.3 & $0.478,0.744$ \\
Holland & 1.17 & $0.899,10.44$ & 0.61 & $0.151,0.346$ \\
Sweden & 0.45 & $0.253,0.640$ & 0.33 & $0.390,0.576$ \\
Slovenia & 1.21 & $0.843,10.580$ & 0.48 & $0.372,0.749$ \\
\hline
\end{tabular}


unaffected by the treatment of comorbid conditions in the model. In the second confirmatory analyses where a count of comorbid conditions and an IV Poisson are used to address potential endogeneity between hearing impairment and other conditions, a positive and statistically significant relationship between hearing impairment and the use of doctor and hospital services is again seen. In the third confirmatory analysis, again the sign of estimate and significance of hearing impairment across countries are shown to be unaffected.

\section{Discussion}

The premise of this investigation is that additional healthcare needs arise as a result of suboptimally managed hearing impairment and that those needs will manifest themselves in additional - potentially avoidable - use of other healthcare services. An extensive literature resource linking hearing impairment to poorer mental and emotional well-being as well as to acute episodes of physical ill-health (e.g., related to falls) exists. Studies in Iceland (16), Australia (17), and the USA (18) show an increased risk of all-cause mortality among older persons 50 and over (16), those aged over 66 (18), and those aged over 69 with a hearing impairment relative to those without such an impairment. Studies by Viljanen et al (19) in Finland and Lin and Ferrucci (20) in the USA have demonstrated an increased risk of falls among older persons with hearing impairment relative to those without such an impairment, a recent literature review underscoring these relationships (8). Hearing impairment has also been associated with cognitive decline, and various studies have demonstrated relationships with depression, anxiety, and poorer social relationships (21-23). That additional needs arise from what may be induced morbidity is, therefore, perhaps to be expected.

Five of the countries examined in this study exhibited low response rates in respect of important sociodemographic information, such as years of education, age, or marital status: France, Switzerland, Austria, Estonia and Luxembourg. For example, in respect of France, while 4,506 individuals were included in the SHARE sample, only 523 provided details of their marital status and only 215 provided details of their years of education. It is unclear why response rates should vary across countries, but that it might impact on sample representativeness and the validity of inferences drawn is clear. In respect of these countries, we thought the usable sample was reduced to such an extent that legitimate questions as to how representative the remaining sample was of the overall sample could be raised. While results for these countries are reported in the tables, for completeness no inference is drawn from them as to the nature of relationships between service use and hearing impairment.
With respect to the remaining 9 countries, the comparative analysis shows (with the exception of Denmark in respect of secondary care) a consistent pattern across primary and secondary care in which hearing impairment is associated with increased service use. The amount by which service use increased in the presence of hearing impairment, controlling for a range of covariates, including age and other measures of health, clearly varies between countries. However, it is important to examine the additional service use with respect to primary and secondary care together as well as separately to obtain a fuller appreciation of the factors that might -underlie these relationships. Taking both primary and secondary care together, the combined marginal effects from the 2 regressions (i.e., additional service use) on hearing impairment were between (approximately) 1.4 and 1.8 in respect of -Belgium, the Czech Republic, Germany, Italy, the Netherlands, and Slovenia. In the cases of Spain and -Sweden, the combined marginal effects were 0.66 and 0.93 , respectively. In the case of Denmark, while those with hearing impairment used on average 1.25 more primary care visits, they used 0.46 fewer secondary care visits - an issue that we return to below.

Neither differences in overall healthcare spend - measured in terms of U.S. dollars adjusted for purchasing par parity - nor the percentage of gross domestic product (GDP) spent on healthcare offer consistent explanations for the pattern of resource use observed in respect of both primary and secondary care combined. While, for example, Slovenia had a healthcare spend of \$2,595 USPPP adjusted per person (approximately 9.2\% of GDP) in 2013 (24), and Sweden a spend of $\$ 4,244$ USPPP adjusted per person (approximately 9.7\% of GDP) also in 2013, Slovenians with a hearing impairment - relative to those without - undertook more visits to primary and secondary care physicians than their counterparts in Sweden. Similarly, while the percentage of GDP spent on healthcare is lower in Italy $(\$ 3,126$ USPPP adjusted) than Sweden, again visits to primary and secondary care physicians relative to those without a hearing impairment were higher than those exhibited in Sweden.

Some insight into the pattern of service use may be offered through an examination of how hearing impairment is managed across countries. Of the countries included in this analysis, Godinho (25) provides figures for sales of hearing aids per thousand of the population: Spain (2.81 per 1,000), Italy (4.69), Belgium (6.67), Germany (10.84), and Denmark (22.40). The author also offers figures on the number of persons fitted with hearing aids per 1,000 of the population: Italy (2.81), Germany (4.93) and Denmark (12.17), as well as the percentage of persons with hearing loss who received bilateral fitting in Italy (44\%), Germany (76\%), and Denmark (84\%). While incomplete both in terms of the countries covered and the detail provided (how 
good the hearing aids on offer were, what compliance was, etc.), a correlation with healthcare use is evident. Relative to the other countries, Denmark clearly enjoys superior access and - with the exception of Spain - lower levels of total additional service use. A rank ordering in terms of sales per 1,000 inhabitants and total service use, for example, is evident between Denmark, Germany, and -Belgium. While Italy has a lower total service use than Belgium or Germany, its operation of a gatekeeping system to secondary care (which is argued to provide for more efficient use of care services) may, in part, explain this, though it is important not to over-interpret results. It is unclear why Spain should have much lower additional service use patterns. Of the western economies included in the analysis, even though per capita expenditure on care is lowest in Spain ( $\$ 2,846$ [USPPP adjusted] compared with $\$ 4,526$ for Belgium, $\$ 4,812$ for Germany, $\$ 4,552$ for Denmark, $\$ 3,126$ for Italy, $\$ 5,601$ for Holland, and $\$ 4,244$ for Sweden), it is still higher for those in Slovenia $(\$ 2,595)$ and the Czech Republic $(\$ 1,982)$, where higher additional service use is recorded.

As noted, it is important to consider both total additional use and use at different levels of the service to obtain a fuller appreciation of the factors underlying service patterns. With respect to the distribution across primary and secondary care sectors, a relatively clear and consistent pattern of service use is evident. In those countries where primary care physicians act as gatekeepers to secondary care (Spain, Italy, Holland, Slovenia, and Denmark) the marginal effect (i.e., the additional service use) associated with hearing impairment in primary care is higher than that associated with secondary care. In contrast, in those countries where there is no gate-keeping role for primary care, either the marginal effect in secondary care associated with hearing impairment is higher than in primary care (Czech Republic, Germany, Sweden) or the difference between primary and secondary care is modest (Belgium). This pattern is entirely consistent with primary care physicians ensuring more efficient use of what are generally more expensive secondary care services through appropriate referral systems, though other explanations may exist.

Our analyses show, consistent with O'Neill et al (26), that hearing impairment is associated with the additional use of healthcare in the clear majority of the countries examined. This is borne out by confirmatory analyses reported in Appendix 4, 5, and 6. Our comparative approach demonstrates the consistency of experience in this regard; however, importantly, the variation in experience between countries provides valuable potential insights into how such demands might be managed. Clearly, where primary care acts as a gatekeeper to hospital services, the extent of the increase in use of hospital services - often more expensive than those in primary care - are reduced. It is also clear that where access to hearing-assistive technologies is greatest, the impact of hearing impairment on health service use is also reduced. In this respect, the case of Denmark is perhaps instructive where the use of inpatient services by respondents with a hearing impairment is actually less than that (other variables controlled for) of those without a hearing impairment.

It is difficult to discern a clear pattern in the relative size of the marginal effects reported in Table III and Supplementary Table 1. -Frequently, the additional number of visits associated with hearing impairment is about half that associated with diabetes in primary care, for example. However, as is clear from the experience of Germany and Italy, the relative size can be higher or lower. This is similar to inpatient services where, again, the size of the marginal effect for hearing impairment vary relative to other conditions.

There are a number of limitations to our analysis. The reduced sample size in respect of a number of countries renders us mute in respect of the relationship between hearing impairment and health service use in these instances. That the experience in these countries may be consistent with that reported here for other countries remains plausible. We were not able to observe how severe hearing impairment is in the case of those reporting a hearing impairment or how this might vary between countries. While there is every reason to believe that self-reported hearing impairment would be positively correlated with objectively measured hearing levels, different thresholds of measured impairment may operate in different countries before self-reported impairment is triggered (or vice versa). A lack of precision also exists with respect to several of the independent variables in our analysis. For example, in relation to Alzheimer disease, the wording of the survey also refers to dementia, organic brain syndrome, senility, or any other serious memory impairment. Not only is this broad, but also one must remember that the responses are self-reported. Consequently, there may be some degree of measurement error, collinearity, and possible endogeneity in respect of several conditions. However, outside of a large prospective panel survey with lengthy follow-up in which objective measures of disease severity were made, data limitations are inevitable. That our results remain robust across confirmatory analyses offers some reassurance in respect of our conclusions as well as helping to frame a future research agenda in this area. Ultimately though, our analysis points to an association between service use and hearing impairment although there is some uncertainty as to the precise magnitude of the association. It is a limitation that we have been unable to disaggregate service use further within primary care or to examine the relationship between hearing impairment and other services, such as outpatient care. 
We chose not to pool data across countries in an attempt to estimate a model in which the role of such variables could be examined using multilevel modelling. It could be argued that not exploring the role of such variables within a pooled sample using such an approach is a limitation of our study. The use of multilevel models where the number of countries involved is small has received recent attention in the literature (2). For nonlinear models, such as those used here, it has been argued that 30 countries or more are required for the production of reliable estimates. The number of countries available in this study was considerably less than this. Were we to include additional data (e.g., access to hearing assistive technology), the number of countries in the analysis would be further reduced. In these circumstances, it is unclear how informative the production of estimates from a multi-level model would be even for comparison with those produced. As the separate analyses of individual countries presented in the paper provides insight into the role of hearing -impairment, as well as variations in that role between countries, it was decided not to add this additional layer of complexity to our results - though it is an issue that could be explored in further research.

Hearing impairment is generally associated with the increased use of primary and secondary healthcare services when other aspects of health have been controlled. The additional use is likely related to health problems occasioned as a result of impairment. Where access to hearing assistive technologies are greatest (Denmark), the use of services by the hearing impaired not only is seen to be less than elsewhere, but also is less than that among those with normal hearing in the case of hospital services. This suggests that expanded access to services may have a role in reducing the burden of illness associated with hearing impairment. This and the impact of system structure, particularly those that afforded primary care, on the burden of illness associated with hearing impairment warrant further investigation.

\section{Declaration of Conflicting Interest}

The authors declare that there is no conflict of interest.

\section{Funding}

Both authors were funded by the RL2013/16 HRB grant during the time of this work.

\section{References}

1. Bernabei V, Morini V, Moretti F, et al. Vision and hearing impairments are associated with depressiveanxiety syndrome in Italian elderly. Aging Ment Health. 2011;15(4):467-474.

2. Bryan ML and Jenkins SP. Multi-level modelling of country effects: a cautionary tale. Eur Sociol Rev. 2016;32(1):3-22.

3. Cieśla K, Lewandowska M and Skarżyński H. Health-related quality of life and mental distress in patients with partial deafness: preliminary findings. Eur Arch Otorhinolaryngol. 2016;273(3):767-776.

4. Dee A, Kearns K, ONeill C, et al. The direct and indirect costs of both overweight and obesity: a systematic review. BMC Res Notes. 2014;7(1):242.

5. Dee A, Callinan A, Doherty E, et al. Overweight and obesity on the island of Ireland: an estimation of costs. BMJ Open. 2015;5(3):e006189.

6. Fellinger J, Holzinger D, Gerich J and Goldberg D. Mental distress and quality of life in the hard of hearing. Acta Psychiatr Scand. 2007;115(3):243-245.

7. Fisher D, Li CM, Chiu MS, et al. Impairments in hearing and vision impact on mortality in older people: the AGESReykjavik Study. Age Ageing. 2014;43(1):69-76.

8. Foley DM, Frick KD and Lin FR. Association between hearing loss and healthcare expenditures in older adults. $J$ Am Geriatr Soc. 2014;62(6):1188-1189.

9. Genther DJ, Frick KD, Chen D, Betz J and Lin FR. Association of hearing loss with hospitalization and burden of disease in older adults. JAMA. 2013;309(22): 2322-2324.

10. Genther DJ, Betz J, Pratt S, et al. Health ABC study. Association of hearing impairment and mortality in older adults. J Gerontol A Biol Sci Med Sci. 2015;70(1): 85-90.

11. Godinho L. What is the most efficient reimbursement system in Europe? A statistical look at the wide range of European hearing aid reimbursement systems. The Hearing Review. 2015. http://www.hearingreview.com/2015/12/efficient-reimbursement-system-europe/. Accessed November 27, 2017.

12. Honeycutt A, Dunlap L, et al. Centers for Disease Control and Prevention (CDC). Economic costs associated with mental retardation, cerebral palsy, hearing loss, and vision impairmentUnited States, 2003. MMWR Morb Mortal Wkly Rep. 2004;53(3):57-59.

13. Jiam NT, Li C and Agrawal Y. Hearing loss and falls: A systematic review and meta-analysis. Laryngoscope. 2016;126(11):2587-2596.

14. Karpa MJ, Gopinath B, Beath K, et al. Associations between hearing impairment and mortality risk in older persons: the Blue Mountains Hearing Study. Ann Epidemiol. 2010;20(6):452-459.

15. Kervasdoué J. and Hartmann L. Economic impact of hearing loss in France and developed countries: a survey of academic literature 2005-2015. http://www.ehima.com/wpcontent/-uploads/2016/05/FinalReportHearingLossV5.pdf. Accessed-November 27, 2017.

16. Lin FR, Ferrucci L, Metter EJ, An Y, Zonderman AB and Resnick SM. Hearing loss and cognition in the Baltimore Longitudinal Study of Aging. Neuropsychology. 2011;25(6):763-770.

17. Mohr PE, Feldman JJ, Dunbar JL, et al. The societal costs of severe to profound hearing loss in the United States. Int J Technol Assess Health Care. 2000;16(4): 1120-1135.

18. Nelson DI, Nelson RY, Concha-Barrientos M and Fingerhut M. The global burden of occupational noise-induced hearing loss. Am J Ind Med. 2005;48(6):446-458. 
19. O'Neill C. and Lamb B. Archbold, S. 2016. Cost implications for changing candidacy or access to service within a publicly funded healthcare system? Cochlear Implants International. 2016;17(Suppl.1):31-5.

20. O'Neill C, Archbold SM, O'Donoghue GM, et al. Indirect costs, cost-utility variations and the funding of paediatric cochlear implantation. Int $J$ Pediatr Otorhinolaryngol. 2001;58(1):53-7.

21. Taylor PS, Faeth I, Marks MK, et al. Cost of treating otitis media in Australia. Expert Rev Pharmacoecon Outcomes Res. 2009;9(2):133-141.
22. Viljanen A, Kaprio J, Pyykkö I, et al. Hearing as a predictor of falls and postural balance in older female twins. $J$ Gerontol A Biol Sci Med Sci. 2009;64(2):312-317.

23. WHO Regional Office for Europe. Health for all data base (online/offline database). Copenhagen, WHO Regional Office for Europe. http://www.euro.who.int/ en/data-and-evidence/databases/european-health-for-alldatabase-hfa-db.

24. Survey of Health Ageing and Retirement (SHARE), 2016 http://www.share-project.org/. Accessed August 2016.

\section{Appendix I}

Questions on use of health services:

Now please think about the last 12 months. About how many times in total have you seen or talked to a medical doctor or qualified nurse about your health? Please exclude dentist visits and hospital stays, but include emergency room or outpatient clinic visits.

Please also count contacts by telephone or other means.

Please include all kind of therapists here (i.e. also vocational therapists, physiotherapists, osteopath, psychiatrists, psychologists, homeopaths).

How many nights altogether have you spent in hospitals during the last twelve months? 


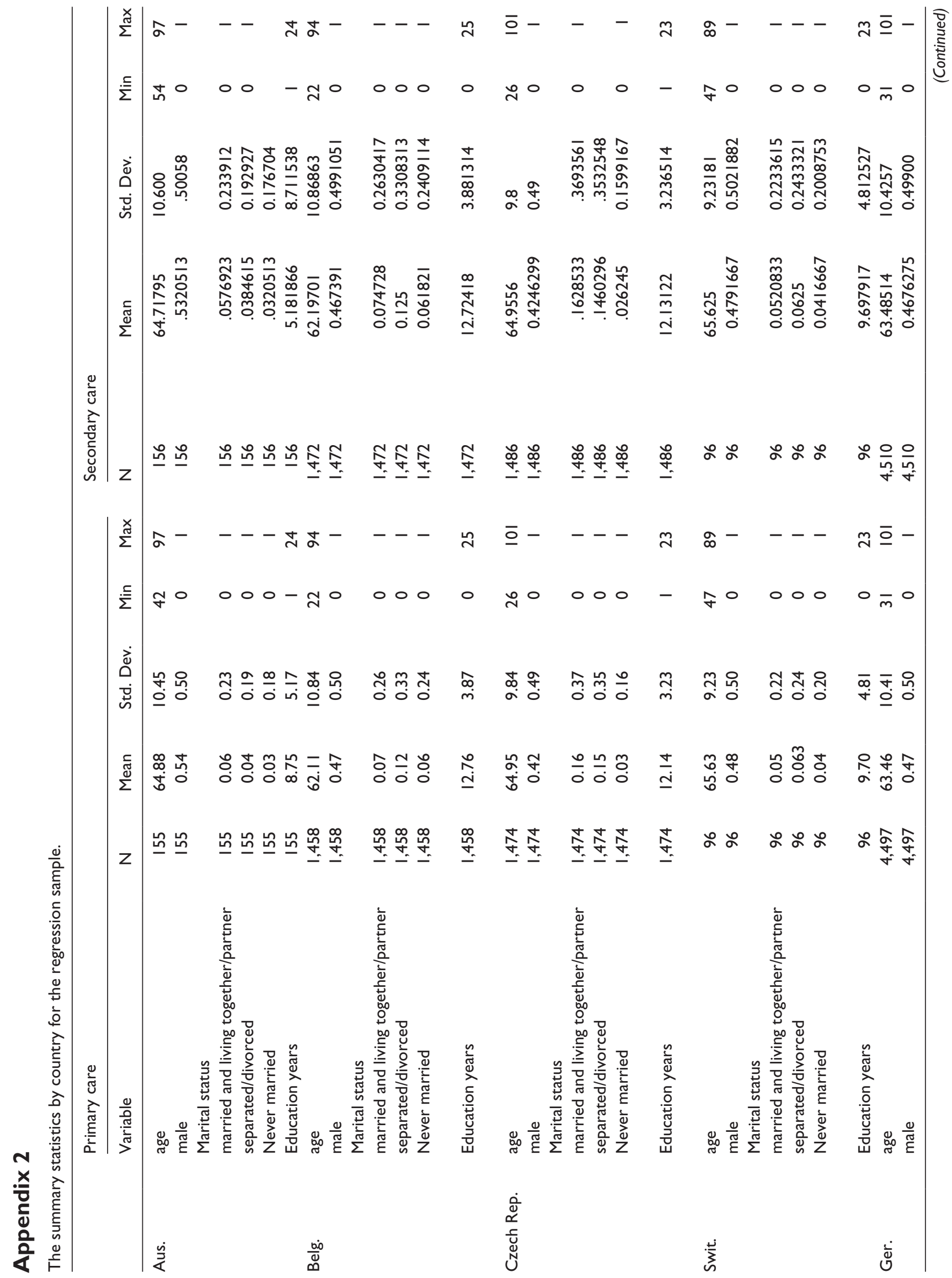




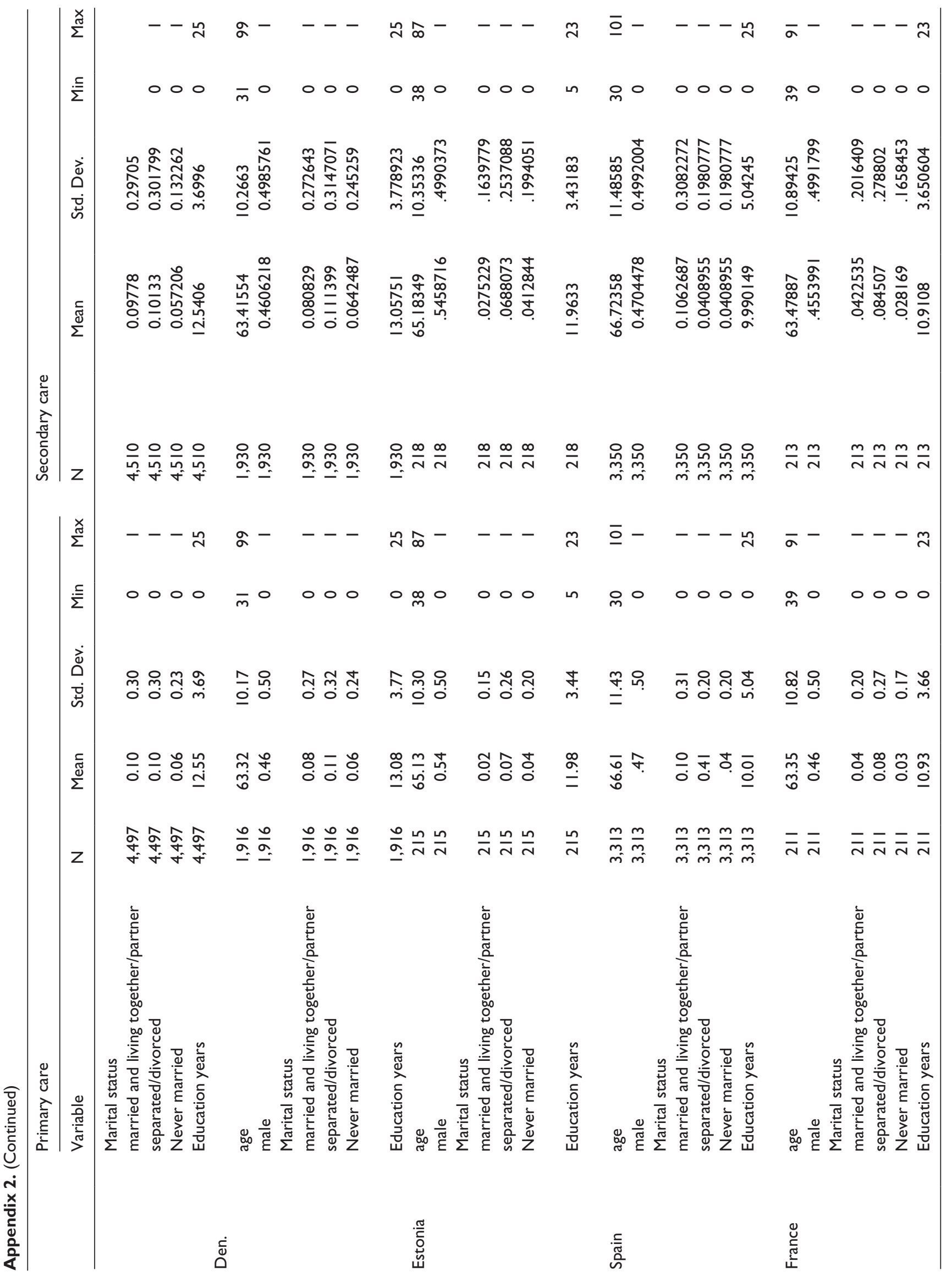




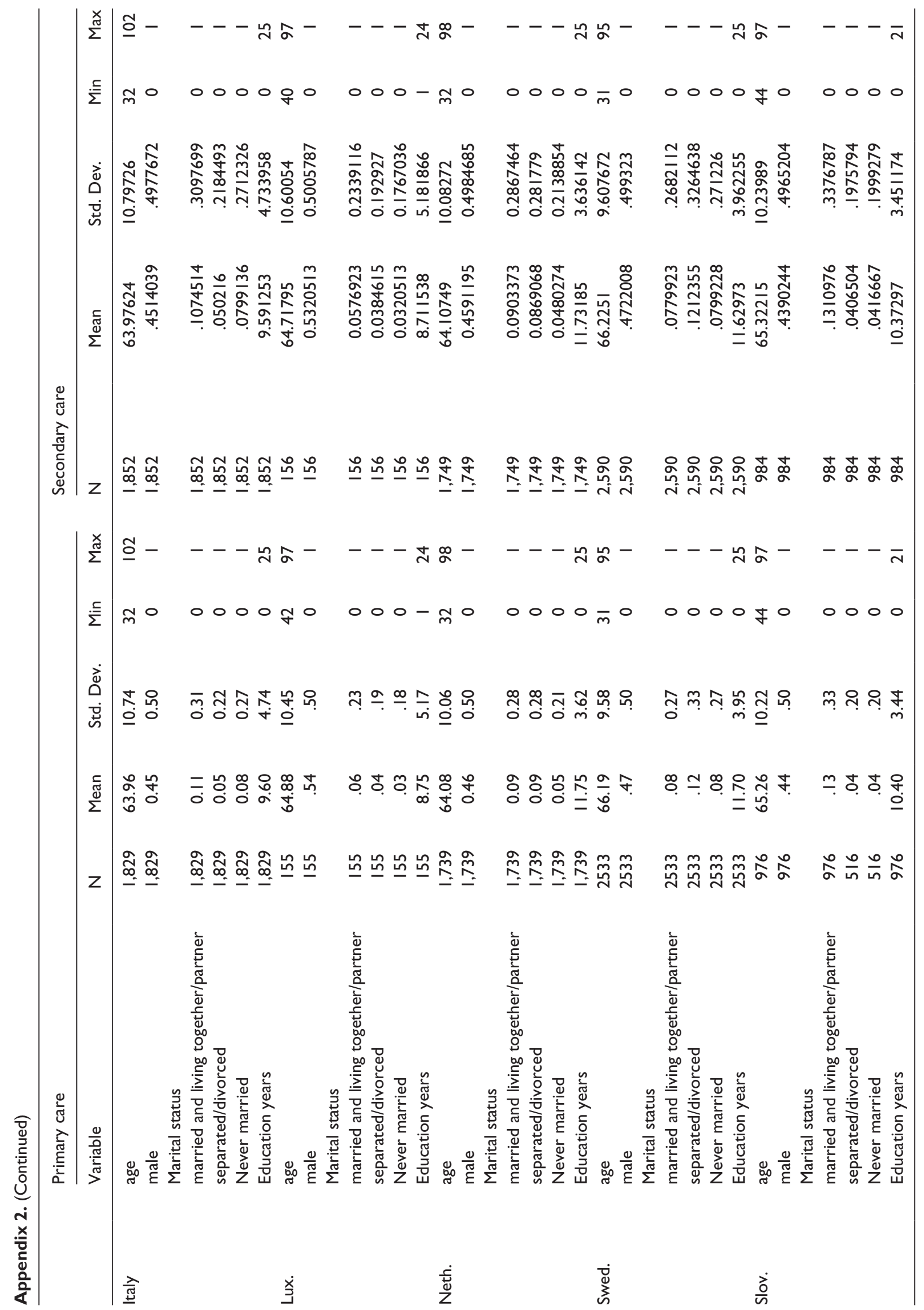




\section{Appendix 3}

Table 3. Primary care.

\begin{tabular}{|c|c|c|c|c|c|c|c|}
\hline & Austria & Belgium & Czech Republic & Switzerland & Germany & Denmark & Estonia \\
\hline \multicolumn{8}{|c|}{ Dependent variable: the number of times seen medical doctor/qualified nurse in the past 12 months } \\
\hline \multirow[t]{2}{*}{ Diabetes } & -0.249 & $2.148 * * *$ & $2.421 * * *$ & $2.946 * * *$ & $2.532^{* * *}$ & $1.967 * * *$ & $3.900 * * *$ \\
\hline & $(1.046)$ & $(0.216)$ & $(0.184)$ & $(1.069)$ & $(0.123)$ & $(0.174)$ & $(0.482)$ \\
\hline \multirow[t]{2}{*}{ Hypertension } & $3.804 * * *$ & $1.248 * * *$ & 1.701 **** & 1.134 & $1.267^{* * * *}$ & $0.998 * * *$ & -0.0582 \\
\hline & $(0.538)$ & $(0.158)$ & $(0.159)$ & $(0.907)$ & $(0.0968)$ & $(0.122)$ & $(0.373)$ \\
\hline \multirow[t]{2}{*}{ Heart attack } & $1.888 * * *$ & $1.904 * * *$ & $1.214 * * *$ & -0.454 & $2.680 * * *$ & $1.214 * * *$ & $2.018 * * *$ \\
\hline & $(0.689)$ & $(0.233)$ & $(0.211)$ & $(1.061)$ & $(0.127)$ & $(0.157)$ & $(0.433)$ \\
\hline \multirow[t]{2}{*}{ Stroke } & $8.930 * * *$ & $3.421 * * *$ & $1.036 * * *$ & $-12.49 *$ & $2.096 * * *$ & $1.265^{* * * *}$ & $2.946 * * *$ \\
\hline & (I.448) & $(0.390)$ & $(0.290)$ & $(6.689)$ & $(0.170)$ & $(0.238)$ & $(0.540)$ \\
\hline \multirow[t]{2}{*}{ Cataracts } & $1.874 * *$ & 0.223 & $2.142^{* * * *}$ & -2.391 & $0.687^{* * *}$ & -0.0279 & $3.748 * * *$ \\
\hline & $(0.846)$ & $(0.260)$ & $(0.227)$ & $(1.483)$ & $(0.14 I)$ & $(0.175)$ & $(0.686)$ \\
\hline \multirow[t]{2}{*}{ cholesterol } & $-1.520 * *$ & -0.0739 & $1.883^{* * * *}$ & $-2.57 I^{* *}$ & -0.110 & $0.619 * * *$ & $1.493 * * *$ \\
\hline & $(0.623)$ & $(0.164)$ & $(0.173)$ & $(1.034)$ & $(0.112)$ & $(0.128)$ & $(0.47 \mathrm{I})$ \\
\hline Chronic lung & -0.195 & $1.903 * * *$ & $3.107^{* * *}$ & $8.25 I^{* * * *}$ & $1.888^{* * * *}$ & $2.250 * * *$ & 0.744 \\
\hline Disease & $(1.163)$ & $(0.26 I)$ & $(0.250)$ & $(1.58 I)$ & $(0.144)$ & $(0.167)$ & $(0.692)$ \\
\hline \multirow[t]{2}{*}{ Cancer } & $6.240 * * *$ & $4.354 * * *$ & $3.107^{* * * *}$ & 6.124*** & $4.033^{*} * * *$ & $3.790 * * *$ & $4.957 * * *$ \\
\hline & $(0.754)$ & $(0.232)$ & $(0.268)$ & $(1.015)$ & $(0.124)$ & $(0.148)$ & $(0.690)$ \\
\hline \multirow[t]{2}{*}{ Stomach } & -1.240 & $1.196 * * *$ & $4.156 * * *$ & -0.505 & $0.544 * * *$ & $1.265 * * *$ & $-3.001 * * *$ \\
\hline & $(1.158)$ & $(0.224)$ & $(0.270)$ & (1.476) & $(0.193)$ & $(0.215)$ & $(0.7 \mid 0)$ \\
\hline \multirow[t]{2}{*}{ Hip fracture } & $4.275^{* *}$ & $1.880 * * *$ & 0.0424 & -1.205 & $3.231 * * *$ & $3.497 * * *$ & 2.926 \\
\hline & $(1.917)$ & $(0.407)$ & $(0.430)$ & $(1.521)$ & $(0.249)$ & $(0.310)$ & $(2.476)$ \\
\hline \multirow[t]{2}{*}{ Other fracture } & -0.819 & $2.063 * * *$ & -0.0870 & $6.886 * * *$ & $1.490 * * *$ & $0.617^{* * *}$ & -0.369 \\
\hline & $(0.842)$ & $(0.226)$ & $(0.273)$ & $(1.052)$ & $(0.124)$ & $(0.159)$ & $(0.746)$ \\
\hline \multirow[t]{2}{*}{ Alzheimer } & $8.700 * * *$ & -0.0839 & $-9.177 * * *$ & & $1.367 * * *$ & $4.743 * * *$ & -1.445 \\
\hline & $(\mathrm{I} .40 \mathrm{I})$ & $(0.621)$ & $(1.464)$ & & $(0.332)$ & $(0.634)$ & $(1.098)$ \\
\hline \multirow[t]{2}{*}{ Emotional } & $5.049 * * *$ & $3.589 * * *$ & 4.119*** & -0.833 & $4.142^{* * *}$ & $2.385^{* * * *}$ & $2.921 * * *$ \\
\hline & $(1.116)$ & $(0.218)$ & $(0.380)$ & (I.346) & $(0.135)$ & $(0.191)$ & $(0.645)$ \\
\hline \multirow[t]{2}{*}{ Rheumatoid } & $5.870 * * *$ & $2.536 * * *$ & $1.684^{* * * *}$ & -0.437 & $2.029 * * *$ & $2.143 * * *$ & $-1.344 * *$ \\
\hline & $(0.795)$ & $(0.245)$ & $(0.206)$ & $(1.500)$ & $(0.128)$ & $(0.239)$ & $(0.625)$ \\
\hline \multirow[t]{2}{*}{ Osteoarthritis } & $3.188^{* * *}$ & $1.219 * * *$ & $1.652^{* * * *}$ & 0.198 & $1.979 * * *$ & $1.558^{* * * *}$ & 0.419 \\
\hline & $(1.002)$ & $(0.170)$ & $(0.176)$ & $(0.899)$ & $(0.108)$ & $(0.119)$ & $(0.623)$ \\
\hline \multirow[t]{2}{*}{ eyesight } & 0.0937 & $-0.705^{* * *}$ & $0.809 * * *$ & $2.677 * * *$ & $0.385^{* * *}$ & $-0.437 * *$ & $2.150 * * *$ \\
\hline & $(0.652)$ & $(0.174)$ & $(0.161)$ & $(0.736)$ & $(0.109)$ & $(0.189)$ & $(0.402)$ \\
\hline \multirow[t]{2}{*}{ Hear } & 0.405 & $0.980 * * *$ & $0.835^{* * *}$ & 0.844 & $0.469 * * *$ & $1.247^{* * *}$ & -0.293 \\
\hline & $(0.585)$ & $(0.184)$ & $(0.179)$ & (I.309) & $(0.115)$ & $(0.144)$ & $(0.424)$ \\
\hline \multirow[t]{2}{*}{ Age } & $1.886 * * *$ & $-0.367 * * *$ & 0.0177 & -0.294 & $-0.222 * * *$ & 0.0554 & -0.137 \\
\hline & $(0.276)$ & $(0.0605)$ & $(0.0772)$ & $(0.435)$ & $(0.0480)$ & $(0.0574)$ & $(0.193)$ \\
\hline age2 & $-0.0137 * * *$ & $0.00272 * * *$ & -0.000491 & 0.00296 & $0.00154 * * *$ & $-9.75 e-05$ & 0.000758 \\
\hline & $(0.00205)$ & $(0.000465)$ & $(0.000578)$ & $(0.00321)$ & $(0.000361)$ & $(0.000429)$ & $(0.00146)$ \\
\hline Gender & $-1.354 * * *$ & $-0.937 * * *$ & $-0.364 * *$ & 0.573 & -0.0204 & $-0.275^{* *}$ & $-|.5| \mid * * *$ \\
\hline$($ male $=I)$ & $(0.481)$ & $(0.152)$ & $(0.162)$ & $(0.698)$ & $(0.0954)$ & $(0.1 \mid 3)$ & $(0.358)$ \\
\hline Marital status & & & & & & & \\
\hline married and living & $-5.187 * * *$ & $1.324 * * *$ & -0.264 & 2.070 & $0.602 * * *$ & $0.798 * * *$ & $-1.622 * * *$ \\
\hline together/partner & $(0.567)$ & $(0.234)$ & $(0.213)$ & $(1.518)$ & $(0.152)$ & $(0.180)$ & $(0.626)$ \\
\hline separated/divorced & $-|.81|$ & $0.66 I^{* *}$ & $-2.085 * * *$ & $8.994 * * *$ & $-0.362^{*}$ & $1.502^{* * * *}$ & -0.348 \\
\hline & $(1.491)$ & $(0.3 \mid 0)$ & $(0.417)$ & $(2.90 I)$ & $(0.194)$ & $(0.262)$ & $(0.964)$ \\
\hline Never married & $2.807 * *$ & -0.304 & -0.232 & $6.478 * * *$ & $0.758 * * *$ & $-0.420 * *$ & -0.773 \\
\hline & (I.382) & $(0.276)$ & $(0.222)$ & $(2.013)$ & $(0.165)$ & $(0.184)$ & $(1.048)$ \\
\hline Education years & 0.0455 & $-0.0809 * * *$ & $-0.207 * * *$ & $-0.135^{* *}$ & $0.0367 * * *$ & $0.115^{* * * *}$ & -0.0201 \\
\hline & $(0.0455)$ & $(0.0195)$ & $(0.0242)$ & $(0.0687)$ & $(0.0129)$ & $(0.0152)$ & $(0.054 \mathrm{I})$ \\
\hline Parkinson & & $6.604 * * *$ & $6.394 * * * *$ & & $7.805^{* * * *}$ & 7.280 **** & \\
\hline & & $(0.624)$ & $(0.621)$ & & $(0.338)$ & $(0.548)$ & \\
\hline $\begin{array}{l}\text { Constant } \\
\text { Observations }\end{array}$ & 155 & $\mathrm{I}, 458$ & $\mathrm{I}, 474$ & 96 & 4,497 & 1,916 & 215 \\
\hline
\end{tabular}


Primary care cont'd

\begin{tabular}{|c|c|c|c|c|c|c|c|}
\hline & Spain & France & Italy & Luxemborg & Holland & Sweden & Slovenia \\
\hline \multicolumn{8}{|c|}{ Dependent variable: the number of times seen medical doctor/qualified nurse in the past 12 months } \\
\hline \multirow[t]{2}{*}{ Diabetes } & $1.385^{* * * *}$ & -0.320 & $0.116 * * *$ & -0.249 & $2.370 * * *$ & $0.227 * * *$ & $1.716 * * *$ \\
\hline & $(0.101)$ & $(0.642)$ & $(0.0238)$ & $(1.046)$ & $(0.17 I)$ & $(0.0323)$ & $(0.193)$ \\
\hline \multirow[t]{2}{*}{ Hypertension } & $0.877^{* * *}$ & -0.674 & $0.188 * * *$ & $3.804 * * *$ & $0.790 * * *$ & $0.109 * * *$ & $1.218^{* * *}$ \\
\hline & $(0.0826)$ & $(0.421)$ & $(0.0191)$ & $(0.538)$ & $(0.133)$ & $(0.0226)$ & $(0.159)$ \\
\hline \multirow[t]{2}{*}{ Heart attack } & $1.799 * * *$ & $3.974 * * *$ & $0.252 * * *$ & $1.888 * * *$ & $1.507 * * *$ & $0.26 I^{* * * *}$ & $2.430 * * *$ \\
\hline & $(0.110)$ & $(0.584)$ & $(0.0248)$ & $(0.689)$ & $(0.161)$ & $(0.0324)$ & $(0.191)$ \\
\hline \multirow[t]{2}{*}{ Stroke } & $2.207^{* * *}$ & $4.509 * * *$ & 0.486 *** & $8.930 * * *$ & $1.245^{* * *}$ & $0.235^{* * *}$ & $-0.713^{* *}$ \\
\hline & $(0.195)$ & $(1.033)$ & $(0.0344)$ & $(1.448)$ & $(0.247)$ & $(0.0379)$ & $(0.349)$ \\
\hline \multirow[t]{2}{*}{ Cataracts } & -0.0436 & 0.418 & $0.0618 * *$ & I.874** & 0.287 & 0.0431 & -0.138 \\
\hline & $(0.119)$ & $(0.738)$ & $(0.0304)$ & $(0.846)$ & $(0.209)$ & $(0.03 \mid 4)$ & $(0.263)$ \\
\hline \multirow[t]{2}{*}{ cholesterol } & 0.0658 & $1.356 * * *$ & $0.213^{* * *}$ & $-1.520 * *$ & $1.171 * * *$ & $0.147 * * *$ & -0.00136 \\
\hline & $(0.0873)$ & $(0.445)$ & $(0.0203)$ & $(0.623)$ & $(0.147)$ & $(0.0272)$ & $(0.182)$ \\
\hline Chronic lung & $1.622 * * *$ & $3.335^{* * *}$ & $0.209 * * *$ & -0.195 & $2.34 I * * *$ & $0.172 * * *$ & $0.750 * *$ \\
\hline Disease & $(0.135)$ & $(0.727)$ & $(0.0325)$ & $(1.163)$ & $(0.163)$ & $(0.0430)$ & $(0.306)$ \\
\hline \multirow[t]{2}{*}{ Cancer } & $2.764 * * *$ & $2.700 * * *$ & $0.629 * * *$ & $6.240 * * *$ & $3.693 * * *$ & $0.420 * * *$ & $4.560 * * *$ \\
\hline & $(0.125)$ & $(0.582)$ & $(0.0264)$ & $(0.754)$ & $(0.169)$ & $(0.0290)$ & $(0.226)$ \\
\hline \multirow[t]{2}{*}{ Stomach } & $1.042^{* * *}$ & 1.137 & $0.120 * * *$ & -1.240 & $1.499 * * *$ & $0.196 * * *$ & $-0.563^{*}$ \\
\hline & $(0.154)$ & $(0.734)$ & $(0.0408)$ & $(I .158)$ & $(0.292)$ & $(0.04 \mid 8)$ & $(0.304)$ \\
\hline \multirow[t]{2}{*}{ Hip fracture } & $0.826 * * *$ & -1.808 & $-0.105^{*}$ & $4.275^{* *}$ & 0.435 & 0.0614 & $-1.123 * *$ \\
\hline & $(0.218)$ & (I.I49) & $(0.0545)$ & $(1.917)$ & $(0.305)$ & $(0.0545)$ & $(0.497)$ \\
\hline \multirow[t]{2}{*}{ Other fracture } & $2.038 * * *$ & 1.023 & $0.264 * * *$ & -0.819 & $0.87 I^{* * *}$ & $0.220 * * *$ & $2.035^{* * *}$ \\
\hline & $(0.11 I)$ & $(0.984)$ & $(0.0319)$ & $(0.842)$ & $(0.189)$ & $(0.0327)$ & $(0.230)$ \\
\hline \multirow[t]{2}{*}{ Alzheimer } & 0.101 & -0.112 & $0.208 * * *$ & $8.700 * * *$ & $-2.149 * * *$ & $1.136 * * *$ & I.I44*** \\
\hline & $(0.198)$ & $(1.364)$ & $(0.0499)$ & $(\mathrm{I} .40 \mathrm{I})$ & $(0.705)$ & $(0.0603)$ & $(0.389)$ \\
\hline \multirow[t]{2}{*}{ Emotional } & $2.097 * * *$ & $2.418 * * *$ & $0.325 * * *$ & $5.049 * * *$ & $1.209 * * *$ & $0.466 * * *$ & $1.979 * * *$ \\
\hline & $(0.119)$ & $(0.568)$ & $(0.0310)$ & $(1.116)$ & $(0.245)$ & $(0.0356)$ & $(0.224)$ \\
\hline \multirow[t]{2}{*}{ Rheumatoid } & -0.0293 & $-\mid 1.31 * *$ & $0.288^{* * *}$ & $5.870 * * *$ & $1.942 * * *$ & $0.216 * * *$ & -0.208 \\
\hline & $(0.108)$ & $(4.622)$ & $(0.0274)$ & $(0.795)$ & $(0.229)$ & $(0.05 I I)$ & $(0.250)$ \\
\hline \multirow[t]{2}{*}{ Osteoarthritis } & $1.24 I^{* * * *}$ & 2.476 *** & -0.0360 & $3.188^{* * *}$ & $1.068^{*} * *$ & $0.332 * * *$ & $1.934 * * *$ \\
\hline & $(0.121)$ & $(0.423)$ & $(0.0238)$ & $(1.002)$ & $(0.146)$ & $(0.024 I)$ & $(0.333)$ \\
\hline \multirow[t]{2}{*}{ Eyesight } & $1.262^{* * *}$ & $-0.792 *$ & $0.0965^{* * *}$ & 0.0937 & $-0.264^{*}$ & $0.0668 * *$ & $-0.530 * * *$ \\
\hline & $(0.0862)$ & $(0.446)$ & $(0.0184)$ & $(0.652)$ & $(0.138)$ & $(0.0264)$ & $(0.162)$ \\
\hline \multirow[t]{2}{*}{ Hear } & $0.357 * * *$ & $-1.022 * *$ & $0.104 * * *$ & 0.405 & $1.170 * * *$ & $0.119 * * *$ & $1.211 * * *$ \\
\hline & $(0.0943)$ & $(0.494)$ & $(0.0219)$ & $(0.585)$ & $(0.138)$ & $(0.026 I)$ & $(0.188)$ \\
\hline \multirow[t]{2}{*}{ Age } & $0.105^{* * *}$ & $-0.419 * *$ & $0.0840^{* * * *}$ & $1.886 * * *$ & -0.0514 & $-0.0627^{* * *}$ & $0.47 I^{* * * *}$ \\
\hline & $(0.0390)$ & $(0.173)$ & $(0.0083 \mathrm{I})$ & $(0.276)$ & $(0.0647)$ & $(0.0114)$ & $(0.0967)$ \\
\hline age2 & $-0.000603 * *$ & $0.00338 * * *$ & $-0.000476 * * *$ & $-0.0137 * * *$ & 0.000504 & $0.000447 * * *$ & $-0.0035 \mathrm{I} * * *$ \\
\hline & $(0.00028 I)$ & $(0.00128)$ & $(6.01 \mathrm{e}-05)$ & $(0.00205)$ & $(0.000477)$ & $(8.40 e-05)$ & $(0.0007 \mid 4)$ \\
\hline Gender & $-0.36 I^{* * *}$ & $-1.835^{* * *}$ & $-0.162 * * *$ & $-1.354 * * *$ & $-0.697 * * *$ & -0.0344 & $0.624 * * *$ \\
\hline$($ male $=I)$ & $(0.0832)$ & $(0.409)$ & $(0.0185)$ & $(0.48 \mathrm{I})$ & $(0.125)$ & $(0.0218)$ & $(0.159)$ \\
\hline Marital status & -0.209 & $4.408^{* * *}$ & $0.289 * * *$ & $-5.187 * * *$ & $-0.984 * * *$ & $0.0792 * *$ & $-0.613 *$ \\
\hline married and living & $(0.191)$ & $(0.934)$ & $(0.0380)$ & $(0.567)$ & $(0.183)$ & $(0.0310)$ & $(0.350)$ \\
\hline together/partner & $0.550 * * *$ & 1.420 & $0.142 * * *$ & $-|.81|$ & $1.56 \mid * * *$ & $0.119 * * *$ & $-0.822^{* *}$ \\
\hline & $(0.196)$ & $(1.103)$ & $(0.0305)$ & $(1.491)$ & $(0.321)$ & $(0.0392)$ & $(0.383)$ \\
\hline separated/divorced & $-0.266 * *$ & -0.153 & $-0.0547 * *$ & $2.807 * *$ & -0.254 & -0.0219 & 0.0390 \\
\hline & $(0.120)$ & $(0.791)$ & $(0.0273)$ & $(1.382)$ & $(0.200)$ & $(0.0385)$ & $(0.253)$ \\
\hline Never married & $-0.0434 * * *$ & $-0.173 * * *$ & $-0.00900 * * *$ & 0.0455 & -0.00887 & $-0.0168 * * *$ & $-0.0930 * * *$ \\
\hline & $(0.00825)$ & $(0.0510)$ & $(0.0021 I)$ & $(0.0455)$ & $(0.0170)$ & $(0.00282)$ & $(0.0231)$ \\
\hline Education years & $2.453 * * *$ & 2.850 & $0.285^{* * * *}$ & & $3.915^{* * *}$ & $0.693 * * *$ & -0.0494 \\
\hline & $(0.250)$ & $(2.633)$ & $(0.07 \mathrm{II})$ & & $(0.445)$ & $(0.1 I I)$ & $(0.7 I I)$ \\
\hline Parkinson & & & $-1.637 * * *$ & & & $3.230 * * *$ & \\
\hline & & & $(0.286)$ & & & $(0.385)$ & \\
\hline Constant & $3,3 \mid 3$ & 211 & 1,829 & 155 & 1,739 & 2,533 & 976 \\
\hline
\end{tabular}


Secondary care.

\begin{tabular}{|c|c|c|c|c|c|c|c|}
\hline & Austria & Belgium & Czech Republic & Switzerland & Germany & Denmark & Estonia \\
\hline \multicolumn{8}{|c|}{ Dependent variable: the number of times seen medical doctor/qualified nurse in the past 12 months } \\
\hline \multirow[t]{2}{*}{ Diabetes } & 0.0901 & I.198*** & $0.599 * * *$ & 0.691 & $0.989 * * *$ & $0.708 * * *$ & $1.650 * * *$ \\
\hline & $(0.507)$ & $(0.0916)$ & $(0.1 \mathrm{II})$ & $(0.834)$ & $(0.0592)$ & $(0.0657)$ & $(0.297)$ \\
\hline \multirow[t]{2}{*}{ Hypertension } & $3.47 \mid * * *$ & $0.761 * * *$ & $-0.171 *$ & 0.876 & $0.292 * * *$ & $-0.348 * * *$ & 0.345 \\
\hline & $(0.402)$ & (0.0739) & $(0.0966)$ & $(0.898)$ & (0.0499) & $(0.0548)$ & $(0.21 \mathrm{I})$ \\
\hline \multirow[t]{2}{*}{ Heart attack } & $-1.425 * * *$ & I.37I $* * *$ & $1.150 * * *$ & $-4.570 * * *$ & $1.289 * * *$ & $0.246 * * *$ & 0.391 \\
\hline & $(0.502)$ & $(0.0901)$ & $(0.117)$ & $(1.700)$ & $(0.0593)$ & $(0.0632)$ & $(0.240)$ \\
\hline \multirow[t]{2}{*}{ Stroke } & $8.418^{* * *}$ & $2.110 * * *$ & $0.515^{* * * *}$ & -20.31 & $1.219 * * *$ & $0.740 * * *$ & $3.587 * * *$ \\
\hline & $(0.827)$ & $(0.140)$ & $(0.165)$ & $(632,744)$ & $(0.074 I)$ & $(0.0838)$ & $(0.364)$ \\
\hline \multirow[t]{2}{*}{ Cataracts } & $1.890 * * *$ & $-0.239 * *$ & $1.868 * * *$ & -49.58 & -0.0229 & $0.47 \mathrm{I} * * *$ & 2.822 *** \\
\hline & $(0.589)$ & $(0.105)$ & $(0.126)$ & $(10,0 \mid 4)$ & $(0.0688)$ & $(0.0627)$ & $(0.372)$ \\
\hline \multirow[t]{2}{*}{ Cholesterol } & $-0.967 * *$ & $-0.885^{* * * *}$ & 0.0969 & $1.57 \mid$ & $-0.350 * * *$ & $0.385^{* * *}$ & $-0.568 *$ \\
\hline & $(0.4 I I)$ & $(0.0846)$ & $(0.1 I I)$ & $(0.959)$ & $(0.0581)$ & $(0.0546)$ & $(0.299)$ \\
\hline Chronic lung & 0.957 & $1.725^{* * * *}$ & $1.909 * * *$ & $4.695^{* *}$ & $1.050 * * *$ & $1.400 * * *$ & 2.736 *** \\
\hline Disease & $(0.622)$ & $(0.0977)$ & $(0.14 I)$ & $(2.054)$ & $(0.0668)$ & $(0.0624)$ & $(0.361)$ \\
\hline \multirow[t]{2}{*}{ Cancer } & $3.755^{* * *}$ & 0.33 I*** & $1.687 * * *$ & $8.469 * * *$ & $1.484 * * *$ & $1.377^{* * *}$ & $2.930 * * *$ \\
\hline & $(0.482)$ & $(0.119)$ & $(0.153)$ & $(1.240)$ & $(0.0602)$ & $(0.0605)$ & $(0.405)$ \\
\hline \multirow[t]{2}{*}{ Stomach } & I.388* & $-0.366 * * *$ & I.408*** & -0.508 & $0.442 * * *$ & $0.544 * * *$ & $-2.180 * * *$ \\
\hline & $(0.817)$ & $(0.1 \mid 3)$ & $(0.170)$ & $(0.780)$ & $(0.0873)$ & $(0.0807)$ & $(0.480)$ \\
\hline \multirow[t]{2}{*}{ Hip fracture } & -31.68 & $0.894 * * *$ & $0.848^{* * * *}$ & 1.996 & $0.326 * *$ & $1.483^{* * * *}$ & -19.64 \\
\hline & $(1,073)$ & $(0.173)$ & $(0.219)$ & $(3.23 I)$ & $(0.131)$ & $(0.0953)$ & $(2,354)$ \\
\hline \multirow[t]{2}{*}{ Other fracture } & $3.112 * * *$ & $-0.307 * *$ & 0.0864 & -2.078 & $1.000 * * *$ & $-0.148 * *$ & 0.590 \\
\hline & $(0.493)$ & $(0.137)$ & $(0.158)$ & $(3.160)$ & $(0.0585)$ & $(0.0706)$ & $(0.408)$ \\
\hline \multirow[t]{2}{*}{ Alzheimer } & 1.607 & $-1.978 * * *$ & 0.548 & & $-1.528 * * *$ & 0.220 & $-7.638^{* * * *}$ \\
\hline & $(1.325)$ & $(0.282)$ & $(0.549)$ & & $(0.192)$ & $(0.263)$ & $(1.090)$ \\
\hline \multirow[t]{2}{*}{ Emotional } & $3.732^{* * * *}$ & $1.036 * * *$ & $4.114 * * *$ & -36.96 & $1.613^{* * *}$ & $-0.367 * * *$ & $2.130 * * *$ \\
\hline & $(0.68 I)$ & $(0.109)$ & $(0.180)$ & $(3,428)$ & $(0.0661)$ & $(0.09 \mid 4)$ & $(0.348)$ \\
\hline \multirow[t]{2}{*}{ Rheumatoid } & -6.147 *** & $0.206^{*}$ & $-0.705^{* * *}$ & $-6.610 * *$ & -0.0337 & $-1.489 * * * *$ & $-2.114 * * *$ \\
\hline & $(1.091)$ & $(0.118)$ & $(0.143)$ & $(2.657)$ & $(0.0696)$ & $(0.187)$ & $(0.490)$ \\
\hline \multirow[t]{2}{*}{ Osteoarthritis } & -4.677 *** & $-0.228 * * *$ & 0.0872 & $-7.144 * * * *$ & $-0.242 * * *$ & 0.0212 & $-2.961 * * *$ \\
\hline & $(1.7 \mid 9)$ & $(0.08 \mid 5)$ & $(0.110)$ & $(\mathrm{I} .593)$ & $(0.0586)$ & $(0.0523)$ & $(0.694)$ \\
\hline \multirow[t]{2}{*}{ Eyesight } & -0.165 & $-0.158^{*}$ & $-0.700 * * *$ & $2.415^{* *}$ & 0.0268 & 0.646 *** & 0.231 \\
\hline & $(0.56 \mathrm{I})$ & $(0.0838)$ & $(0.104)$ & $(1.177)$ & $(0.0547)$ & $(0.0613)$ & $(0.234)$ \\
\hline \multirow[t]{2}{*}{ Hear } & $3.670 * * *$ & $0.611 * * *$ & $0.882 * * *$ & $3.547 * * *$ & $1.005^{* * *}$ & $-0.458 * * *$ & $0.820 * * *$ \\
\hline & $(0.417)$ & $(0.0825)$ & $(0.104)$ & $(0.835)$ & $(0.0538)$ & $(0.0705)$ & $(0.238)$ \\
\hline \multirow[t]{2}{*}{ Age } & 0.279 & $0.508 * * *$ & $0.145^{* * * *}$ & $-1.022 * *$ & $-0.200 * * *$ & -0.00507 & -0.178 \\
\hline & $(0.200)$ & $(0.0430)$ & $(0.0492)$ & $(0.517)$ & $(0.0238)$ & $(0.0217)$ & $(0.138)$ \\
\hline \multirow[t]{2}{*}{ age2 } & -0.00174 & $-0.00342 * * *$ & $-0.000598^{*}$ & $0.00948 * * *$ & $0.00171 * * *$ & 0.000111 & 0.00146 \\
\hline & $(0.00147)$ & $(0.000315)$ & $(0.000357)$ & $(0.00362)$ & $(0.000176)$ & $(0.000159)$ & $(0.00102)$ \\
\hline Gender & 0.283 & $0.192 * * *$ & 0.0600 & 0.821 & $0.668^{* * *}$ & -0.0431 & $-1.318 * * *$ \\
\hline$($ male $=I)$ & $(0.372)$ & $(0.0739)$ & $(0.101)$ & $(0.835)$ & $(0.0500)$ & $(0.0484)$ & $(0.253)$ \\
\hline married and living & -1.188 & $1.950 * * *$ & $-0.506 * * *$ & $-1.377 * * *$ & $1.25 \mathrm{I} * * *$ & $0.912 * * *$ & 1.083 \\
\hline together/partner & $(0.734)$ & $(0.159)$ & $(0.133)$ & $(0.134)$ & $(0.0915)$ & $(0.103)$ & $(0.8 \mid 3)$ \\
\hline separated/divorced & 2.536 & $-0.708^{* * *}$ & 0.397 & 31.76 & $0.485^{* * *}$ & $0.886 * * *$ & $-1.473 * * *$ \\
\hline & $(2.926)$ & $(0.105)$ & $(0.355)$ & $(19.93)$ & $(0.108)$ & $(0.145)$ & $(0.0857)$ \\
\hline Never married & -0.0456 & $0.400 * * *$ & $-0.630 * * *$ & II.74 & 0.114 & -0.0294 & $4.290 * *$ \\
\hline & $(0.623)$ & $(0.121)$ & $(0.121)$ & $(7.661)$ & $(0.0776)$ & $(0.0683)$ & $(1.892)$ \\
\hline Education years & -0.0367 & $-0.106 * * *$ & $-0.278 * * *$ & $-0.249 * * *$ & $-0.0282^{* * *}$ & -0.00125 & -0.0287 \\
\hline & $(0.0364)$ & $(0.00959)$ & $(0.0151)$ & $(0.0777)$ & $(0.00662)$ & $(0.00655)$ & $(0.0344)$ \\
\hline Parkinson & & -0.491 & 0.398 & & $0.500 * *$ & 0.610 & \\
\hline & & $(0.498)$ & $(0.466)$ & & $(0.2 \mid 4)$ & $(0.425)$ & \\
\hline $\begin{array}{l}\text { Constant } \\
\text { Observations }\end{array}$ & 156 & $\mathrm{I}, 472$ & I,486 & 96 & 4,510 & 1,930 & 218 \\
\hline
\end{tabular}


Secondary care cont'd

\begin{tabular}{|c|c|c|c|c|c|c|c|}
\hline & Spain & France & Italy & Luxemborg & Holland & Sweden & Slovenia \\
\hline \multicolumn{8}{|c|}{ Dependent variable: the number of times seen medical doctor/qualified nurse in the past 12 months } \\
\hline \multirow[t]{2}{*}{ Diabetes } & $0.406 * * *$ & $2.294^{* * * *}$ & $0.174^{* * *}$ & 0.0901 & $0.602 * * *$ & $1.205 * * *$ & $0.245^{* *}$ \\
\hline & $(0.04 \mid 2)$ & $(0.337)$ & $(0.0546)$ & $(0.507)$ & $(0.0577)$ & $(0.0478)$ & $(0.107)$ \\
\hline \multirow[t]{2}{*}{ Hypertension } & -0.0209 & -0.297 & $-0.0774 *$ & $3.47 \mid * * *$ & $0.144 * * *$ & $-0.503 * * *$ & $0.656 * * *$ \\
\hline & $(0.0366)$ & $(0.261)$ & $(0.0465)$ & $(0.402)$ & $(0.0498)$ & $(0.0455)$ & $(0.0936)$ \\
\hline \multirow[t]{2}{*}{ Heart attack } & $0.578 * * *$ & $2.012^{* * *}$ & $0.828 * * *$ & $-1.425 * * *$ & $0.584 * * *$ & $0.64 I * * *$ & $1.489 * * *$ \\
\hline & $(0.0430)$ & $(0.280)$ & $(0.0480)$ & $(0.502)$ & $(0.0535)$ & $(0.0527)$ & $(0.0982)$ \\
\hline \multirow[t]{2}{*}{ stroke } & $0.886^{* * * *}$ & 0.375 & 1.246 **** & $8.418^{* * * *}$ & 0.411 **** & $0.287 * * *$ & $-1.433 * * *$ \\
\hline & $(0.0648)$ & $(0.554)$ & $(0.0594)$ & $(0.827)$ & $(0.0716)$ & $(0.06 \mid 4)$ & $(0.224)$ \\
\hline \multirow[t]{2}{*}{ cataracts } & $0.150 * * *$ & $1.906 * * *$ & -0.331 *** & $1.890 * * *$ & $-0.176 * *$ & $-0.869 * * *$ & $-0.665^{* * * *}$ \\
\hline & $(0.0450)$ & $(0.324)$ & $(0.0707)$ & $(0.589)$ & $(0.0844)$ & $(0.0652)$ & $(0.158)$ \\
\hline \multirow[t]{2}{*}{ cholesterol } & -0.223 *** & $-1.799 * * *$ & 0.0223 & $-0.967^{* *}$ & $0.425^{* * *}$ & $0.687 * * *$ & $-0.360 * * *$ \\
\hline & $(0.04 \mid 2)$ & $(0.329)$ & $(0.0503)$ & $(0.4 I I)$ & $(0.0520)$ & $(0.0476)$ & $(0.105)$ \\
\hline Chronic lung & $0.701 * * * *$ & $2.962 * * *$ & $0.477 * * *$ & 0.957 & $0.277^{* * * *}$ & $0.527 * * *$ & $0.728 * * *$ \\
\hline disease & $(0.0493)$ & $(0.353)$ & $(0.0704)$ & $(0.622)$ & $(0.0573)$ & $(0.0734)$ & $(0.14 I)$ \\
\hline \multirow[t]{2}{*}{ cancer } & $0.862^{* * *}$ & $2.7 \mid 4^{* * *}$ & $1.327^{* * *}$ & $3.755^{* * * *}$ & $0.634^{* * * *}$ & $1.263^{* * * *}$ & $2.40 I^{* * * *}$ \\
\hline & $(0.0493)$ & $(0.298)$ & $(0.0484)$ & $(0.482)$ & $(0.0603)$ & $(0.0488)$ & $(0.122)$ \\
\hline \multirow[t]{2}{*}{ stomach } & $0.248 * * *$ & $0.661 *$ & $-0.409 * * *$ & I.388* & $0.699 * * *$ & $0.177^{* *}$ & $-1.695^{* * *}$ \\
\hline & $(0.064 I)$ & $(0.353)$ & $(0.128)$ & $(0.817)$ & $(0.0840)$ & $(0.0840)$ & $(0.213)$ \\
\hline \multirow[t]{2}{*}{ Hip fracture } & $1.095^{* * *}$ & $1.793 * * *$ & $0.84 I^{* * *}$ & -31.68 & $0.605^{* * *}$ & $1.056 * * *$ & $0.639 * * *$ \\
\hline & $(0.0618)$ & $(0.449)$ & $(0.0837)$ & $(I, 073)$ & $(0.0830)$ & $(0.0807)$ & $(0.224)$ \\
\hline \multirow[t]{2}{*}{ Other fracture } & $0.234 * * *$ & -0.0393 & $0.640 * * *$ & $3.112 * * *$ & $0.264 * * *$ & -0.342 *** & $0.958^{* * * *}$ \\
\hline & $(0.0498)$ & $(0.492)$ & $(0.0679)$ & $(0.493)$ & $(0.0634)$ & $(0.0775)$ & $(0.122)$ \\
\hline \multirow[t]{2}{*}{ Alzheimer } & $-0.512 * * *$ & $-3.407 * * *$ & $1.052 * * *$ & 1.607 & -11.89 & $2.936 * * *$ & $1.702^{* * * *}$ \\
\hline & $(0.0805)$ & $(1.174)$ & $(0.0837)$ & $(1.325)$ & $(568.9)$ & $(0.0609)$ & $(0.149)$ \\
\hline \multirow[t]{2}{*}{ emotional } & $0.151 * *$ & $1.509 * * *$ & $0.435 * * *$ & $3.732 * * *$ & -0.0410 & $0.901 * * *$ & $0.855^{* * *}$ \\
\hline & $(0.0589)$ & $(0.324)$ & $(0.0690)$ & $(0.681)$ & $(0.0975)$ & $(0.0635)$ & $(0.1 \mid I)$ \\
\hline \multirow[t]{2}{*}{ Rheumatoid } & -0.00993 & 0.620 & $-0.442 * * *$ & $-6.147 * * *$ & -0.0158 & $-0.546 * * *$ & $1.467 * * *$ \\
\hline & $(0.0455)$ & $(\mathrm{I} .548)$ & $(0.0788)$ & $(1.091)$ & $(0.0864)$ & $(0.110)$ & $(0.110)$ \\
\hline \multirow[t]{2}{*}{ Osteoarthritis } & $0.275^{* * *}$ & $-0.702^{* *}$ & 0.0450 & $-4.677 * * *$ & $0.170 * * *$ & $-0.490 * * *$ & $0.619 * * *$ \\
\hline & $(0.0528)$ & $(0.289)$ & $(0.0547)$ & $(1.719)$ & $(0.053 \mathrm{I})$ & $(0.0607)$ & $(0.175)$ \\
\hline \multirow[t]{2}{*}{ eyesight } & $0.160 * * *$ & -0.120 & 0.0407 & -0.165 & -0.0446 & -0.0438 & $0.65 I^{* * * *}$ \\
\hline & $(0.0385)$ & $(0.284)$ & $(0.0460)$ & $(0.561)$ & $(0.0508)$ & $(0.0479)$ & $(0.0879)$ \\
\hline \multirow[t]{2}{*}{ hear } & $0.301 * * *$ & 0.0288 & $0.435^{* * *}$ & $3.670 * * *$ & $0.248 * * *$ & $0.454 * * *$ & $0.560 * * *$ \\
\hline & $(0.0385)$ & $(0.240)$ & $(0.0476)$ & $(0.417)$ & $(0.0497)$ & $(0.0438)$ & $(0.0961)$ \\
\hline \multirow[t]{2}{*}{ age } & $0.0706 * * * *$ & 0.0619 & $0.356 * * *$ & 0.279 & 0.0167 & $-0.132 * * *$ & $0.438 * * *$ \\
\hline & $(0.0188)$ & $(0.137)$ & $(0.0225)$ & $(0.200)$ & $(0.0269)$ & $(0.0210)$ & $(0.0648)$ \\
\hline age2 & $-0.000317^{* *}$ & 0.000201 & $-0.00237 * * *$ & -0.00174 & -0.000179 & $0.000977 * * *$ & $-0.00308^{* * *}$ \\
\hline & $(0.000 \mid 30)$ & $(0.000959)$ & $(0.000157)$ & $(0.00 \mid 47)$ & $(0.000198)$ & $(0.000152)$ & $(0.00047 \mathrm{I})$ \\
\hline Gender & $0.235^{* * * *}$ & -0.181 & $0.398 * * *$ & 0.283 & $0.108 * *$ & 0.00832 & $0.429 * * *$ \\
\hline$(\mathrm{male}=\mathrm{I})$ & $(0.0389)$ & $(0.245)$ & $(0.0442)$ & $(0.372)$ & $(0.0472)$ & $(0.0422)$ & $(0.0904)$ \\
\hline Marital status & -0.108 & $1.956 * *$ & $-0.459 * * *$ & -1.188 & 0.0787 & $0.559 * * *$ & $-1.020 * * *$ \\
\hline married and living & $(0.0917)$ & $(0.972)$ & $(0.151)$ & $(0.734)$ & $(0.074 I)$ & $(0.0545)$ & $(0.143)$ \\
\hline together/partner & $0.304 * * *$ & 11.80 ** & $0.539 * * *$ & 2.536 & 0.0543 & $0.928 * * *$ & $-1.269 * * *$ \\
\hline & $(0.0962)$ & $(4.895)$ & $(0.0736)$ & $(2.926)$ & $(0.108)$ & $(0.0644)$ & $(0.166)$ \\
\hline separated/divorced & $0.168 * * *$ & $-2.058 * * *$ & $1.112^{* * *}$ & -0.0456 & -0.0311 & $0.321 * * *$ & $-0.694 * * *$ \\
\hline & $(0.0537)$ & $(0.3 \mid 3)$ & $(0.0523)$ & $(0.623)$ & $(0.0698)$ & $(0.0659)$ & $(0.110)$ \\
\hline Never married & $-0.0288 * * *$ & -0.0339 & $0.0462 * * *$ & -0.0367 & $-0.0647 * * *$ & $-0.0732^{* * *}$ & $-0.0960 * * *$ \\
\hline & $(0.00391)$ & $(0.0368)$ & $(0.00463)$ & $(0.0364)$ & $(0.00683)$ & $(0.00572)$ & $(0.0139)$ \\
\hline Education years & $0.231 * *$ & -20.05 & $1.180 * * *$ & & $1.035^{* * *}$ & -0.0404 & $-5.377^{*} * * *$ \\
\hline & $(0.106)$ & $(2,008)$ & $(0.0946)$ & & $(0.120)$ & $(0.450)$ & $(1.125)$ \\
\hline parkinson & & & $-14.22 * * *$ & & & $4.252 * * *$ & \\
\hline & & & $(0.804)$ & & & $(0.7 \mid 3)$ & \\
\hline Constant & 3,350 & 213 & 1,852 & 156 & $\mathrm{I}, 749$ & 2,590 & 984 \\
\hline
\end{tabular}




\section{Appendix 4}

Regression results using index

\begin{tabular}{|c|c|c|c|c|c|c|c|}
\hline & Belgium & Czech Republic & Switzerland & Germany & Denmark & Estonia & Spain \\
\hline \multicolumn{8}{|c|}{ Dependent variable: the number of times seen medical doctor/qualified nurse in the past 12 months } \\
\hline \multirow[t]{2}{*}{ index } & $0.195^{* * *}$ & $0.234 * * *$ & $0.195 * * *$ & $0.202 * * *$ & $0.243 * * *$ & $0.256^{* * *}$ & $0.238 * * *$ \\
\hline & $(0.00547)$ & $(0.00508)$ & $(0.0318)$ & $(0.00255)$ & $(0.00560)$ & $(0.0181)$ & $(0.00430)$ \\
\hline \multirow[t]{2}{*}{ hearing } & $0.106 * * *$ & $0.0894 * * *$ & -0.207 & $0.0390 * * *$ & $0.174 * * *$ & $-0.190 * * * *$ & $0.0735^{* * * *}$ \\
\hline & $(0.0242)$ & $(0.0230)$ & $(0.145)$ & $(0.0128)$ & $(0.0266)$ & $(0.0736)$ & $(0.0201)$ \\
\hline \multirow[t]{2}{*}{ age } & $-0.0531 * * *$ & $0.0226 * *$ & $-0.084 I$ & $-0.0259 * * *$ & $0.0214^{* *}$ & 0.0126 & $0.0230 * * *$ \\
\hline & $(0.00837)$ & $(0.00991)$ & $(0.0582)$ & $(0.00520)$ & $(0.0106)$ & $(0.0359)$ & $(0.00822)$ \\
\hline \multirow[t]{2}{*}{ age2 } & $0.000392 * * *$ & $-0.000226 * * *$ & $0.000702^{*}$ & $0.000177 * * *$ & -0.000116 & -0.000121 & $-0.000154 * * *$ \\
\hline & $(6.4 \mathrm{le}-05)$ & $(7.40 \mathrm{e}-05)$ & $(0.000419)$ & $(3.90 e-05)$ & $(7.89 \mathrm{e}-05)$ & $(0.000270)$ & $(5.91 \mathrm{e}-05)$ \\
\hline \multirow[t]{2}{*}{ male } & $-0.136 * * *$ & $-0.0455^{* *}$ & $0.438 * * *$ & $-0.0172^{*}$ & $-0.0658 * * *$ & $-0.133 * *$ & -0.0225 \\
\hline & $(0.0198)$ & $(0.0205)$ & $(0.0900)$ & $(0.0104)$ & $(0.0205)$ & $(0.0623)$ & $(0.0168)$ \\
\hline \multicolumn{8}{|c|}{ Marital status (reference: living together / partner) } \\
\hline \multirow[t]{2}{*}{ Separated/divorced } & $0.188 * * *$ & -0.0348 & 0.0164 & $0.0838 * * *$ & $0.144 * * *$ & $-0.509 * * *$ & 0.00430 \\
\hline & $(0.0280)$ & $(0.0276)$ & $(0.195)$ & $(0.0162)$ & $(0.0302)$ & $(0.138)$ & $(0.0425)$ \\
\hline \multirow[t]{2}{*}{ Never married } & 0.0521 & $-0.300 * * *$ & $0.901 * * *$ & -0.0261 & $0.246 * * *$ & -0.252 & $0.181 * * *$ \\
\hline & $(0.0397)$ & $(0.07 \mathrm{II})$ & $(0.166)$ & $(0.0227)$ & $(0.0396)$ & $(0.183)$ & $(0.0372)$ \\
\hline \multirow[t]{2}{*}{ widowed } & -0.0555 & $-0.0552^{*}$ & $1.092 * * *$ & $0.0627 * * *$ & $-0.0760 * *$ & -0.261 & -0.0363 \\
\hline & $(0.0395)$ & $(0.0287)$ & $(0.132)$ & $(0.0173)$ & $(0.0376)$ & $(0.213)$ & $(0.0268)$ \\
\hline \multirow[t]{2}{*}{ Education years } & $-0.0127^{* * * *}$ & $-0.0269 * * *$ & $-0.0327 * * *$ & $0.00590 * * *$ & $0.0175^{* * *}$ & 0.00286 & $-0.00862 * * *$ \\
\hline & $(0.00259)$ & $(0.00307)$ & $(0.00952)$ & $(0.00 \mid 43)$ & $(0.00279)$ & $(0.00933)$ & $(0.00174)$ \\
\hline \multirow[t]{2}{*}{ Constant } & $3.493 * * *$ & $1.360 * * *$ & $3.831 *$ & $2.552^{* * *}$ & 0.0508 & 0.954 & 0.266 \\
\hline & $(0.269)$ & $(0.330)$ & $(1.983)$ & $(0.172)$ & $(0.355)$ & $(1.175)$ & $(0.283)$ \\
\hline \multirow[t]{2}{*}{ Observations } & $\mathrm{I}, 458$ & $\mathrm{I}, 474$ & 96 & 4,497 & 1,916 & 215 & 3,313 \\
\hline & France & Italy & Israel & Luxemborg & Holland & Sweden & Slovenia \\
\hline \multicolumn{8}{|c|}{ Dependent variable: the number of times seen medical doctor/qualified nurse in the past 12 months } \\
\hline \multirow[t]{2}{*}{ index } & $0.170 * * *$ & $0.186 * * *$ & $0.387^{* * * *}$ & $0.230 * * *$ & $0.233 * * *$ & $0.231 * * *$ & $0.183^{* * *}$ \\
\hline & $(0.0172)$ & $(0.00492)$ & $(0.00961)$ & $(0.0205)$ & $(0.00588)$ & $(0.00565)$ & $(0.00694)$ \\
\hline \multirow[t]{2}{*}{ hearing } & $-0.159 * *$ & $0.118 * * *$ & $-0.112^{* *}$ & -0.0167 & $0.180 * * *$ & $0.0908^{* * * *}$ & $0.136^{* * * *}$ \\
\hline & $(0.0743)$ & $(0.02 \mid 4)$ & $(0.0461)$ & $(0.083 \mathrm{I})$ & $(0.0245)$ & $(0.0259)$ & $(0.0358)$ \\
\hline \multirow[t]{2}{*}{ age } & $-0.0736 * * *$ & $0.086 I^{* * * *}$ & $0.108 * * *$ & $0.130 * * *$ & $0.0307^{* * * *}$ & $-0.0569 * * *$ & $0.106 * * *$ \\
\hline & $(0.0255)$ & $(0.00802)$ & $(0.023 I)$ & $(0.03 \mid 5)$ & $(0.01 \mid 4)$ & $(0.01 \mid 2)$ & $(0.0185)$ \\
\hline \multirow[t]{2}{*}{ age2 } & $0.000617 * * *$ & $-0.000500 * * *$ & $-0.000748 * * *$ & $-0.00086 \mid * * *$ & $-0.000208 * *$ & $0.000386 * * *$ & $-0.00078 \mid$ |*** \\
\hline & $(0.000 / 87)$ & $(5.76 e-05)$ & $(0.000173)$ & $(0.000231)$ & $(8.37 e-05)$ & $(8.2 \mathrm{le}-05)$ & $(0.000 \mid 36)$ \\
\hline \multirow[t]{2}{*}{ male } & $-0.253 * * *$ & $-0.120 * * *$ & $-0.0855^{* *}$ & -0.0843 & $-0.142 * * *$ & -0.0316 & $0.166 * * *$ \\
\hline & $(0.0577)$ & $(0.0179)$ & $(0.0347)$ & $(0.0656)$ & $(0.02 \mid 4)$ & $(0.0210)$ & (0.0299) \\
\hline \multicolumn{8}{|c|}{ Marital status (reference: living together / partner) } \\
\hline \multirow[t]{2}{*}{ Separated/divorced } & $0.398 * * *$ & $0.275^{* * *}$ & $0.647 * * *$ & $-0.873 * * *$ & $-0.135^{* * *}$ & $0.0677^{* *}$ & -0.0681 \\
\hline & $(0.0880)$ & $(0.0377)$ & $(0.0443)$ & $(0.201)$ & $(0.0380)$ & $(0.0307)$ & $(0.0750)$ \\
\hline Never married & $0.28 \mathrm{I} * *$ & $0.137^{* * *}$ & $-0.425 * * *$ & $-0.628 * *$ & $0.218 * * *$ & $0.109 * * *$ & $-0.256 * * *$ \\
\hline & $(0.142)$ & $(0.0301)$ & $(0.108)$ & $(0.293)$ & $(0.0439)$ & $(0.0389)$ & $(0.0876)$ \\
\hline widowed & 0.121 & $-0.0519 *$ & $-0.69 \mid * * *$ & 0.406 *** & -0.0219 & -0.0303 & 0.0239 \\
\hline & $(0.123)$ & $(0.0267)$ & $(0.0920)$ & $(0.119)$ & $(0.0370)$ & $(0.0382)$ & $(0.0475)$ \\
\hline Education years & $-0.0239 * * *$ & $-0.0086 I^{* * * *}$ & $-0.01111 * * *$ & -0.00522 & -0.00345 & $-0.0154 * * *$ & $-0.0210 * * *$ \\
\hline & $(0.00795)$ & $(0.00210)$ & $(0.00415)$ & $(0.00631)$ & $(0.00302)$ & $(0.00278)$ & $(0.00436)$ \\
\hline Constant & $3.972 * * *$ & $-1.704 * * *$ & $-2.469 * * *$ & $-3.161 * * * *$ & 0.251 & $3.068 * * *$ & $-2.198 * * *$ \\
\hline & $(0.850)$ & $(0.278)$ & $(0.747)$ & $(1.070)$ & $(0.387)$ & $(0.379)$ & $(0.620)$ \\
\hline Observations & 211 & 1,829 & 578 & 155 & 1,739 & 2,533 & 976 \\
\hline
\end{tabular}




\begin{tabular}{|c|c|c|c|c|c|c|c|}
\hline & Belgium & Czech Republic & Switzerland & Germany & Denmark & Estonia & Spain \\
\hline \multicolumn{8}{|c|}{ Dependent variable: number of nights in hospital in the past 12 months } \\
\hline \multirow[t]{2}{*}{ index } & $0.224 * * *$ & $0.184 * * *$ & $-0.404 * * *$ & $0.233^{* * *}$ & $0.357 * * *$ & $0.290 * * *$ & $0.258 * * *$ \\
\hline & $(0.0109)$ & $(0.00827)$ & $(0.0693)$ & $(0.00465)$ & $(0.0121)$ & $(0.03 \mid 4)$ & $(0.00883)$ \\
\hline \multirow[t]{2}{*}{ hearing } & $0.144 * * *$ & $0.331 * * *$ & $0.527 * *$ & $0.400 * * *$ & $-0.387^{* * *}$ & 0.148 & $0.297 * * *$ \\
\hline & $(0.0478)$ & $(0.0347)$ & $(0.217)$ & $(0.0223)$ & $(0.0707)$ & $(0.124)$ & $(0.0409)$ \\
\hline \multirow[t]{2}{*}{ age } & $0.299 * * *$ & $0.0594 * * * *$ & $0.452^{* * *}$ & $-0.0818^{* * *}$ & $-0.0675^{* * *}$ & $0.139 *$ & $0.0790 * * *$ \\
\hline & $(0.0250)$ & $(0.0166)$ & $(0.174)$ & $(0.00962)$ & $(0.0229)$ & $(0.0791)$ & $(0.0200)$ \\
\hline \multirow[t]{2}{*}{ age2 } & $-0.00196 * * *$ & $-0.000306 * *$ & $-0.00215^{*}$ & $0.000679 * * *$ & $0.000603 * * *$ & -0.000930 & $-0.000365^{* * *}$ \\
\hline & $(0.000183)$ & $(0.000120)$ & $(0.00116)$ & $(7.08 \mathrm{e}-05)$ & $(0.000167)$ & $(0.000577)$ & $(0.000138)$ \\
\hline \multirow[t]{2}{*}{ male } & $0.396 * * *$ & 0.0189 & $0.669 * * *$ & $0.334^{* * *}$ & -0.0400 & 0.170 & $0.417^{* * * *}$ \\
\hline & $(0.0418)$ & $(0.0335)$ & $(0.186)$ & $(0.0205)$ & $(0.0485)$ & $(0.116)$ & $(0.0383)$ \\
\hline \multicolumn{8}{|c|}{ Marital status (reference: living together / partner) } \\
\hline \multirow[t]{2}{*}{ Separated/divorced } & $0.994 * * *$ & $-0.183^{* * *}$ & -15.32 & $0.509 * * *$ & $0.642 * * *$ & -0.229 & -0.102 \\
\hline & $(0.05 \mid 5)$ & $(0.0488)$ & $(655.7)$ & $(0.0278)$ & $(0.0635)$ & $(0.243)$ & $(0.118)$ \\
\hline \multirow[t]{2}{*}{ Never married } & $-0.715^{* * *}$ & 0.0708 & $2.128 * * *$ & $0.295 * * *$ & $0.730 * * *$ & -15.08 & $0.291 * * *$ \\
\hline & $(0.145)$ & $(0.0998)$ & $(0.423)$ & $(0.0403)$ & $(0.0825)$ & $(537.8)$ & $(0.0816)$ \\
\hline \multirow[t]{2}{*}{ widowed } & $0.228 * * *$ & $-0.215^{* * *}$ & $2.047 * * *$ & 0.00858 & -0.122 & 0.404 & $0.293 * * *$ \\
\hline & $(0.0673)$ & $(0.0442)$ & $(0.184)$ & $(0.0338)$ & $(0.0867)$ & $(0.303)$ & $(0.0504)$ \\
\hline \multirow[t]{2}{*}{ Education years } & $-0.0810 * * *$ & $-0.0972^{* * *}$ & $-0.131 * * *$ & $-0.00665^{* *}$ & -0.00235 & $-0.0437 * *$ & $-0.0310^{* * * *}$ \\
\hline & $(0.00547)$ & $(0.00490)$ & $(0.0207)$ & $(0.00279)$ & $(0.00659)$ & $(0.0178)$ & $(0.00407)$ \\
\hline \multirow[t]{2}{*}{ Constant } & $-10.38 * * *$ & -0.840 & $-19.38 * * *$ & $2.385^{* * * *}$ & 0.870 & $-4.903 *$ & $-4.490 * * *$ \\
\hline & $(0.842)$ & $(0.570)$ & (6.399) & $(0.323)$ & $(0.781)$ & $(2.676)$ & $(0.719)$ \\
\hline Observations & $\mathrm{I}, 472$ & $\mathrm{I}, 486$ & 96 & 4,510 & 1,930 & 218 & 3,350 \\
\hline
\end{tabular}

\begin{tabular}{|c|c|c|c|c|c|c|c|}
\hline & France & Italy & Israel & Luxemborg & Holland & Sweden & Slovenia \\
\hline \multicolumn{8}{|c|}{ Dependent variable: number of nights in hospital in the past 12 months } \\
\hline \multirow[t]{2}{*}{ index } & $0.299 * * *$ & $0.293 * * *$ & $0.269 * * *$ & $0.189 * * *$ & $0.427 * * *$ & $0.317 * * *$ & $0.28 I^{* * *}$ \\
\hline & $(0.0308)$ & $(0.0112)$ & $(0.0229)$ & $(0.0386)$ & $(0.0140)$ & $(0.00930)$ & $(0.0101)$ \\
\hline \multirow[t]{2}{*}{ hearing } & $0.245^{*}$ & $0.468 * * *$ & $-0.579 * * *$ & $0.716 * * *$ & $0.259 * * *$ & $0.409 * * *$ & $0.413^{* * *}$ \\
\hline & $(0.130)$ & $(0.0458)$ & $(0.117)$ & $(0.119)$ & $(0.0635)$ & $(0.0426)$ & $(0.0589)$ \\
\hline \multirow[t]{2}{*}{ age } & $0.245 * * *$ & $0.292 * * *$ & $-0.286 * * *$ & $0.208^{* * * *}$ & $0.0833^{* *}$ & $-0.180 * * *$ & 0.33 I $* * *$ \\
\hline & $(0.08 I I)$ & $(0.022 I)$ & $(0.0491)$ & $(0.0524)$ & $(0.0344)$ & $(0.0190)$ & $(0.0396)$ \\
\hline \multirow[t]{2}{*}{ age2 } & $-0.00122 * *$ & $-0.00189 * * *$ & $0.00219 * * *$ & $-0.00139 * * *$ & $-0.000713^{* * *}$ & $0.00133^{* * *}$ & $-0.0023 \mid * * *$ \\
\hline & (0.000559) & $(0.000154)$ & $(0.000352)$ & $(0.000370)$ & $(0.000251)$ & $(0.000136)$ & $(0.000288)$ \\
\hline \multirow[t]{2}{*}{ male } & $0.309 * *$ & $0.606 * * *$ & $1.548 * * *$ & 0.136 & $0.211 * * *$ & $0.387^{* * * *}$ & $0.129 * *$ \\
\hline & $(0.124)$ & $(0.0426)$ & $(0.106)$ & $(0.123)$ & $(0.0578)$ & $(0.0395)$ & $(0.054 I)$ \\
\hline \multicolumn{8}{|c|}{ Marital status (reference: living together / partner) } \\
\hline \multirow[t]{2}{*}{ Separated/divorced } & $0.439 * * *$ & $-0.576 * * *$ & $0.578 * * *$ & $0.627 * * *$ & 0.133 & $0.501 * * *$ & $-0.647 * * *$ \\
\hline & $(0.159)$ & $(0.150)$ & $(0.135)$ & $(0.215)$ & $(0.0888)$ & $(0.0528)$ & $(0.175)$ \\
\hline \multirow[t]{2}{*}{ Never married } & $1.009 * * *$ & $0.472^{* * *}$ & $-2.272^{* * *}$ & -0.721 & 0.0708 & $0.785^{* * *}$ & $-1.517^{* * *}$ \\
\hline & $(0.269)$ & $(0.0707)$ & $(0.710)$ & $(0.585)$ & $(0.121)$ & $(0.0627)$ & $(0.3 \mid 8)$ \\
\hline \multirow[t]{2}{*}{ widowed } & $-1.485 * * *$ & $1.082 * * *$ & $2.262 * * *$ & $1.133 * * *$ & 0.0947 & 0.0983 & $-0.425 * * *$ \\
\hline & $(0.5 \mid 3)$ & $(0.0503)$ & $(0.121)$ & $(0.197)$ & $(0.0958)$ & $(0.0647)$ & $(0.0843)$ \\
\hline \multirow[t]{2}{*}{ Education years } & 0.0308 & $0.0456 * * *$ & $-0.117 * * *$ & $-0.0809 * * *$ & $-0.0958 * * *$ & $-0.0850 * * *$ & $-0.0620 * * *$ \\
\hline & $(0.0208)$ & $(0.00463)$ & $(0.0104)$ & $(0.0135)$ & $(0.00850)$ & $(0.00556)$ & $(0.00790)$ \\
\hline \multirow[t]{2}{*}{ Constant } & $-11.85 * * *$ & $-12.36 * * *$ & $8.647 * * *$ & $-6.956 * * *$ & $-2.722 * *$ & $5.753 * * *$ & $-11.30 * * *$ \\
\hline & $(2.921)$ & $(0.793)$ & $(1.614)$ & $(1.859)$ & $(1.161)$ & $(0.659)$ & $(1.350)$ \\
\hline Observations & 213 & 1,852 & 633 & 156 & 1,749 & 2,590 & 984 \\
\hline
\end{tabular}

Standard errors in parentheses

$* * * p<0.01$, ** $p<0.05, * p<0.1$ 


\section{Appendix 5}

Marginal effects using instrument variable.

\begin{tabular}{|c|c|c|}
\hline & Hospital nights & Doctor visits \\
\hline \multirow[t]{2}{*}{ hear } & $7.217 * * *$ & $4.399 * *$ \\
\hline & $(1.653)$ & $(1.716)$ \\
\hline \multirow[t]{2}{*}{ index } & $1.347 * * *$ & $0.436 * * *$ \\
\hline & $(0.0996)$ & $(0.0769)$ \\
\hline \multirow[t]{2}{*}{ age } & 0.0200 & 0.00864 \\
\hline & $(0.180)$ & $(0.142)$ \\
\hline \multirow[t]{2}{*}{ age2 } & -0.000844 & -0.000347 \\
\hline & $(0.00128)$ & $(0.000969)$ \\
\hline \multirow[t]{2}{*}{ education_years } & 0.0568 & 0.0226 \\
\hline & $(0.0381)$ & $(0.0308)$ \\
\hline \multicolumn{3}{|c|}{ Marital status (ref.: living together/partner) } \\
\hline \multirow[t]{2}{*}{ Separated/divorced } & -0.192 & 0.767 \\
\hline & $(0.506)$ & $(0.489)$ \\
\hline \multirow[t]{2}{*}{ Never married } & $1.827 *$ & 0.222 \\
\hline & $(1.019)$ & $(0.561)$ \\
\hline \multirow[t]{2}{*}{ widowed } & -0.0376 & 0.317 \\
\hline & $(0.401)$ & $(0.288)$ \\
\hline Observations & 6,229 & 6,296 \\
\hline
\end{tabular}




\section{Appendix 6}

Model estimated using backwards elimination (marginal effects).

\begin{tabular}{|c|c|c|c|c|c|c|}
\hline & Austria & Belgium & Czech Republic & Swizerland & Germany & Denmark \\
\hline \multicolumn{7}{|c|}{ Dependent variable: the number of times seen medical doctor/qualified nurse in the past 12 months } \\
\hline \multirow{2}{*}{ age } & $1.590 * * *$ & $-0.340 * * *$ & & $0.120 * * *$ & $(0.0463)$ & $(0.00577)$ \\
\hline & $(0.220)$ & $(0.0591)$ & & $(0.0328)$ & $1.279 * * *$ & $0.895^{* * *}$ \\
\hline \multirow[t]{2}{*}{ Hypertention } & $3.384 * * *$ & $1.178 * * *$ & $1.709 * * *$ & & $(0.0953)$ & $(0.121)$ \\
\hline & $(0.498)$ & $(0.154)$ & $(0.159)$ & & $2.669 * * *$ & $1.263 * * *$ \\
\hline \multirow[t]{2}{*}{ Heart attack } & $1.834^{* * * *}$ & $1.807^{* * *}$ & $0.988 * * *$ & & $(0.125)$ & $(0.156)$ \\
\hline & $(0.655)$ & $(0.23 I)$ & $(0.208)$ & & $2.287 * * *$ & $1.247 * * *$ \\
\hline \multirow[t]{2}{*}{ stroke } & $8.710 * * *$ & $3.581 * * *$ & $1.234 * * *$ & $-14.88 * *$ & $(0.169)$ & $(0.235)$ \\
\hline & $(1.119)$ & $(0.369)$ & $(0.286)$ & $(6.113)$ & $0.618^{* * *}$ & \\
\hline \multirow[t]{2}{*}{ cataracts } & $2.387^{* * * *}$ & & $2.033 * * *$ & $-2.083^{*}$ & $(0.14 I)$ & \\
\hline & $(0.791)$ & & $(0.225)$ & $(1.167)$ & & $0.560 * * *$ \\
\hline \multirow[t]{2}{*}{ choles } & $-1.363^{* *}$ & & $1.847^{* * * *}$ & $-2.692 * * *$ & & $(0.128)$ \\
\hline & $(0.593)$ & & $(0.171)$ & $(0.842)$ & $1.882 * * *$ & $2.144 * * *$ \\
\hline \multirow[t]{2}{*}{ lung } & $-3.074 * * *$ & $1.898 * * *$ & $2.962 * * *$ & $7.591 * * *$ & $(0.144)$ & $(0.165)$ \\
\hline & $(1.140)$ & $(0.260)$ & $(0.248)$ & $(1.175)$ & $3.999 * * *$ & $3.698 * * *$ \\
\hline \multirow[t]{2}{*}{ cancer } & $6.948 * * *$ & $4.340 * * *$ & $3.368 * * *$ & $4.735^{* * *}$ & $(0.124)$ & $(0.147)$ \\
\hline & $(0.694)$ & $(0.232)$ & $(0.265)$ & $(0.876)$ & $0.524 * * *$ & $1.165^{* * * *}$ \\
\hline \multirow[t]{2}{*}{ stomach } & $-2.054^{*}$ & $1.233^{* * *}$ & $4.126^{* * *}$ & & $(0.192)$ & $(0.2 \mid 2)$ \\
\hline & $(1.147)$ & $(0.223)$ & $(0.264)$ & & $3.369 * * *$ & $3.483 * * *$ \\
\hline \multirow[t]{2}{*}{ Hip fracture } & $4.535^{* * *}$ & $1.643 * * *$ & & & $(0.248)$ & $(0.308)$ \\
\hline & $(1.755)$ & $(0.403)$ & & & $0.00218^{* * * *}$ & \\
\hline \multirow[t]{2}{*}{ age2 } & $-0.0112 * * *$ & 0.0025 I **** & $-0.000364 * * *$ & & $(0.000347)$ & \\
\hline & $(0.00160)$ & $(0.000450)$ & $(6.15 e-05)$ & & $4.233^{* * * *}$ & $2.642 * * *$ \\
\hline \multirow[t]{2}{*}{ emotional } & $4.505^{* * *}$ & $3.67 \mid$ I*** & $4.146 * * *$ & & $(0.133)$ & $(0.188)$ \\
\hline & (1.098) & $(0.217)$ & $(0.375)$ & & $2.001 * * *$ & $2.379 * * *$ \\
\hline \multirow[t]{2}{*}{ Rheumatoid } & $5.506 * * *$ & $2.586 * * *$ & $1.619 * * *$ & & $(0.128)$ & $(0.237)$ \\
\hline & $(0.727)$ & $(0.243)$ & $(0.205)$ & & $2.022 * * *$ & $1.574 * * *$ \\
\hline \multirow[t]{2}{*}{ Osteoarthritis } & $2.574 * * *$ & $1.246 * * *$ & $1.721 * * *$ & & $(0.108)$ & $(0.118)$ \\
\hline & $(0.936)$ & $(0.169)$ & $(0.175)$ & & & \\
\hline \multirow[t]{2}{*}{ male } & $-1.614 * * *$ & $-0.974 * * * *$ & & & & \\
\hline & $(0.462)$ & $(0.151)$ & & & $2.56 I^{* * *}$ & $1.885^{* * *}$ \\
\hline \multirow[t]{2}{*}{ Diabetes } & & $2.089 * * *$ & $2.454 * * *$ & $4.611 * * *$ & $(0.121)$ & $(0.173)$ \\
\hline & & $(0.21 \mathrm{I})$ & $(0.182)$ & $(0.912)$ & $0.0287 * *$ & $0.097 \mid * * *$ \\
\hline \multirow[t]{2}{*}{ Education years } & & $-0.0807 * * *$ & $-0.223 * * *$ & $-0.206 * * *$ & $(0.0126)$ & $(0.0150)$ \\
\hline & & $(0.0194)$ & $(0.0233)$ & $(0.0583)$ & 1.466 *** & $0.577^{* * *}$ \\
\hline \multirow[t]{2}{*}{ Other fracture } & & 2.208 *** & & $6.274 * * *$ & $(0.124)$ & $(0.158)$ \\
\hline & & $(0.225)$ & & $(0.739)$ & 0.421 I*** & \\
\hline \multirow[t]{2}{*}{ eyesight } & & $-0.781^{* * * *}$ & $0.898^{* * *}$ & $3.837^{* * *}$ & $(0.108)$ & \\
\hline & & $(0.173)$ & $(0.161)$ & $(0.678)$ & $0.428^{* * *}$ & $1.247 * * *$ \\
\hline \multirow[t]{2}{*}{ hear } & & $1.030 * * *$ & $0.757^{* * * *}$ & & $(0.115)$ & $(0.14 I)$ \\
\hline & & $(0.182)$ & $(0.178)$ & & & \\
\hline Observations & 155 & $\mathrm{I}, 458$ & $\mathrm{I}, 474$ & 96 & 4,497 & 1,916 \\
\hline
\end{tabular}


Appendix 6. (Continued)

\begin{tabular}{|c|c|c|c|c|c|c|c|c|}
\hline & Estonia & Spain & France & Italy & Luxemborg & Holland & Sweden & Slovenia \\
\hline \multicolumn{9}{|c|}{ Dependent variable: the number of times seen medical doctor/qualified nurse in the past 12 months } \\
\hline \multirow[t]{2}{*}{ age } & $-0.0315^{*}$ & $0.103 * * *$ & $-0.436 * * *$ & $0.0786 * * *$ & $1.590 * * *$ & & $0.256 * * *$ & $1.729 * * *$ \\
\hline & $(0.0181)$ & $(0.0382)$ & $(0.164)$ & $(0.00818)$ & $(0.220)$ & & $(0.0317)$ & $(0.190)$ \\
\hline \multirow[t]{2}{*}{ Hypertention } & & $0.892 * * *$ & $-0.728^{*}$ & $0.181 * * *$ & $3.384 * * *$ & $0.866 * * *$ & $0.110 * * *$ & $1.200 * * *$ \\
\hline & & $(0.0806)$ & $(0.406)$ & $(0.0189)$ & $(0.498)$ & $(0.132)$ & $(0.0225)$ & $(0.155)$ \\
\hline \multirow[t]{2}{*}{ Heart attack } & $1.755^{* * *}$ & $1.825^{* * * *}$ & $3.744 * * *$ & $0.249 * * *$ & $1.834 * * *$ & $1.678 * * *$ & $0.306 * * *$ & $2.413^{* * *}$ \\
\hline & $(0.4 \mid 2)$ & $(0.108)$ & $(0.540)$ & $(0.0245)$ & $(0.655)$ & $(0.158)$ & $(0.0316)$ & $(0.190)$ \\
\hline \multirow[t]{2}{*}{ stroke } & $2.830 * * *$ & 2.369 *** & $3.864 * * *$ & $0.500 * * *$ & $8.710^{* * * *}$ & $1.207^{* * *}$ & $0.317^{* * *}$ & \\
\hline & $(0.516)$ & $(0.190)$ & $(0.984)$ & $(0.0343)$ & $(1.119)$ & $(0.245)$ & $(0.0367)$ & \\
\hline \multirow[t]{2}{*}{ cataracts } & $3.170 * * *$ & & & $0.0787 * * *$ & $2.387^{* * * *}$ & & $0.132 * * *$ & \\
\hline & $(0.634)$ & & & $(0.0296)$ & $(0.791)$ & & $(0.0303)$ & \\
\hline \multirow[t]{2}{*}{ choles } & $1.388 * * *$ & & $1.281 * * *$ & $0.198 * * *$ & $-1.363^{* *}$ & $1.115^{* * *}$ & $0.122^{* * *}$ & \\
\hline & $(0.430)$ & & $(0.425)$ & $(0.0201)$ & $(0.593)$ & $(0.146)$ & $(0.0270)$ & \\
\hline \multirow[t]{2}{*}{ lung } & & $1.649 * * *$ & $2.657 * * *$ & $0.226 * * *$ & $-3.074 * * *$ & $2.419 * * *$ & $0.229 * * *$ & $0.753^{* *}$ \\
\hline & & $(0.134)$ & $(0.654)$ & $(0.0323)$ & $(I .140)$ & $(0.162)$ & $(0.0420)$ & $(0.30 \mathrm{I})$ \\
\hline \multirow[t]{2}{*}{ cancer } & $5.264 * * *$ & $2.733^{* * * *}$ & $2.505 * * *$ & $0.613 * * *$ & $6.948 * * *$ & $3.530 * * *$ & $0.390 * * *$ & $4.486 * * *$ \\
\hline & $(0.645)$ & $(0.125)$ & $(0.563)$ & $(0.0262)$ & $(0.694)$ & $(0.167)$ & $(0.0289)$ & $(0.221)$ \\
\hline \multirow[t]{2}{*}{ stomach } & $-2.859 * * *$ & $1.094 * * *$ & & $0.0917^{* *}$ & $-2.054^{*}$ & $1.431 * * *$ & $0.140 * * *$ & $-0.708^{* *}$ \\
\hline & $(0.670)$ & $(0.150)$ & & $(0.0406)$ & $(1.147)$ & $(0.289)$ & $(0.04 \mid 8)$ & $(0.293)$ \\
\hline \multirow[t]{2}{*}{ Hip fracture } & & $0.760 * * *$ & & $-0.107 * *$ & $4.535^{* * *}$ & & $-0.0157^{* * *}$ & $-0.0964 * * *$ \\
\hline & & $(0.217)$ & & $(0.054 \mathrm{I})$ & $(\mathrm{I} .755)$ & & $(0.00279)$ & $(0.0226)$ \\
\hline \multirow[t]{2}{*}{ age2 } & & $-0.000585^{* *}$ & $0.00354 * * *$ & $-0.000439 * * *$ & $-0.0112 * * *$ & $0.000136 * * *$ & $0.26 I^{* * * *}$ & $1.954 * * *$ \\
\hline & & $(0.000273)$ & $(0.00121)$ & $(5.89 e-05)$ & $(0.00160)$ & $(4.36 e-05)$ & $(0.0324)$ & $(0.227)$ \\
\hline \multirow[t]{2}{*}{ emotional } & $2.362 * * *$ & $2.205^{* * * *}$ & $2.785^{* * *}$ & $0.328 * * *$ & $4.505^{* * *}$ & $1.27 \mid * * *$ & $0.545^{* * *}$ & $2.104 * * *$ \\
\hline & $(0.553)$ & $(0.117)$ & $(0.538)$ & $(0.0306)$ & (1.098) & $(0.238)$ & $(0.0348)$ & $(0.217)$ \\
\hline \multirow[t]{2}{*}{ Rheumatoid } & $-1.091 *$ & & $-11.04 * *$ & $0.291 * * *$ & $5.506 * * *$ & $1.844 * * *$ & $0.305^{* * *}$ & \\
\hline & $(0.565)$ & & $(4.532)$ & $(0.0273)$ & $(0.727)$ & $(0.225)$ & $(0.050 I)$ & \\
\hline \multirow[t]{2}{*}{ Osteoarthritis } & & $1.234^{* * *}$ & $2.450 * * *$ & & $2.574 * * *$ & $1.074 * * *$ & $0.318 * * *$ & $1.852^{* * *}$ \\
\hline & & $(0.120)$ & $(0.394)$ & & $(0.936)$ & $(0.144)$ & $(0.0236)$ & $(0.326)$ \\
\hline \multirow[t]{2}{*}{ male } & $-1.580 * * *$ & -0.278 *** & $-1.767 * * *$ & $-0.155^{* * *}$ & $-1.614 * * *$ & $-0.713 * * *$ & $0.108 * * *$ & $-0.493 * * *$ \\
\hline & $(0.343)$ & $(0.0795)$ & $(0.388)$ & $(0.0179)$ & $(0.462)$ & $(0.120)$ & $(0.0259)$ & $(0.161)$ \\
\hline \multirow[t]{2}{*}{ Diabetes } & $4.118^{* * *}$ & $1.36 I^{* * * *}$ & & $0.127^{* * *}$ & & $2.248^{* * *}$ & $0.0868^{* * *}$ & $1.204^{* * *}$ \\
\hline & $(0.456)$ & $(0.0998)$ & & $(0.0236)$ & & $(0.168)$ & $(0.0258)$ & $(0.185)$ \\
\hline \multirow[t]{2}{*}{ Education years } & & $-0.0400 * * *$ & $-0.149 * * *$ & $-0.00742 * * *$ & & & $-0.0598 * * *$ & $0.474 * * *$ \\
\hline & & $(0.0082 I)$ & $(0.0501)$ & $(0.00210)$ & & & $(0.0113)$ & $(0.0948)$ \\
\hline \multirow[t]{2}{*}{ Other fracture } & & $1.963 * * *$ & & $0.272 * * *$ & & $0.960 * * *$ & $0.000425 * * *$ & $-0.0035 \mathrm{I} * * *$ \\
\hline & & $(0.110)$ & & $(0.03 \mid 8)$ & & $(0.186)$ & $(8.29 \mathrm{e}-05)$ & $(0.000695)$ \\
\hline \multirow[t]{2}{*}{ eyesight } & $2.205^{* * * *}$ & $1.323 * * *$ & & $0.113 * * *$ & & & & $0.613^{* * *}$ \\
\hline & $(0.389)$ & $(0.0850)$ & & $(0.0 \mid 82)$ & & & & $(0.15 I)$ \\
\hline \multirow[t]{2}{*}{ hear } & & $0.415^{* * * *}$ & $-0.890 *$ & $0.102 * * *$ & & $1.074 * * *$ & & $-1.354 * * *$ \\
\hline & & $(0.0931)$ & $(0.462)$ & $(0.0217)$ & & $(0.138)$ & & $(0.487)$ \\
\hline \multirow[t]{2}{*}{ Constant } & & & & $-1.447 * * *$ & & & $3.125^{* * *}$ & \\
\hline & & & & $(0.282)$ & & & $(0.380)$ & \\
\hline Observations & 215 & $3,3 \mid 4$ & 211 & 1,833 & 155 & 1,739 & 2,540 & 976 \\
\hline
\end{tabular}

Standard errors in parentheses $* * * p<0.01, * * p<0.05, * p<0.1$ 


\begin{tabular}{|c|c|c|c|c|c|c|}
\hline & Austria & Belgium & Czech Republic & Swizerland & Germany & Denmark \\
\hline \multicolumn{7}{|c|}{ Dependent variable: number of nights in hospital in the past 12 months } \\
\hline \multirow[t]{2}{*}{ male } & & & $0.198 * *$ & & $0.680 * * *$ & \\
\hline & & & $(0.0973)$ & & $(0.0487)$ & \\
\hline \multirow[t]{2}{*}{ hear } & $3.544 * * *$ & $0.679 * * *$ & $0.845^{* * *}$ & & $0.988 * * *$ & $-0.423 * * *$ \\
\hline & $(0.356)$ & $(0.0809)$ & $(0.103)$ & & $(0.0535)$ & $(0.0693)$ \\
\hline \multirow[t]{2}{*}{ hypertension } & $3.259 * * *$ & $0.669 * * *$ & $-0.157^{*}$ & $1.898 * * *$ & $0.268 * * *$ & $-0.4 I I * * *$ \\
\hline & $(0.358)$ & $(0.0732)$ & $(0.0940)$ & $(0.5 \mid 2)$ & $(0.0497)$ & $(0.0544)$ \\
\hline \multirow[t]{2}{*}{ Heart attack } & $-0.923 * *$ & $1.469 * * *$ & $1.152 * * *$ & $-6.278 * * *$ & I.246*** & $0.274 * * *$ \\
\hline & $(0.438)$ & $(0.0894)$ & $(0.116)$ & $(1.559)$ & $(0.0592)$ & $(0.0624)$ \\
\hline \multirow[t]{2}{*}{ stroke } & $8.357^{* * *}$ & $1.621 * * *$ & $0.518^{* * *}$ & & $1.274 * * *$ & $0.726 * * *$ \\
\hline & $(0.648)$ & $(0.130)$ & $(0.164)$ & & $(0.0736)$ & $(0.0825)$ \\
\hline \multirow[t]{2}{*}{ cataracts } & $1.647 * * *$ & & $1.835^{* * *}$ & & & $0.460 * * *$ \\
\hline & $(0.488)$ & & $(0.125)$ & & & $(0.06 \mid 2)$ \\
\hline \multirow[t]{2}{*}{ choles } & $-0.904 * *$ & $-0.977 * * *$ & & $-3.322^{* * *}$ & $-0.353 * * *$ & $0.328 * * *$ \\
\hline & $(0.377)$ & $(0.0849)$ & & $(0.748)$ & $(0.0576)$ & $(0.0537)$ \\
\hline \multirow[t]{2}{*}{ eyesight } & $-1.466 * * *$ & $-0.150 *$ & $-0.676 * * *$ & & & $0.700 * * *$ \\
\hline & $(0.524)$ & $(0.0814)$ & $(0.103)$ & & & $(0.0604)$ \\
\hline \multirow[t]{2}{*}{ cancer } & $3.792 * * *$ & $0.332 * * *$ & $1.695^{* * * *}$ & $7.440 * * *$ & $1.502 * * *$ & $1.365^{* * * *}$ \\
\hline & $(0.426)$ & $(0.118)$ & $(0.152)$ & $(0.778)$ & (0.0599) & $(0.0600)$ \\
\hline \multirow[t]{2}{*}{ stomach } & I.470* & -0.34 I*** & $1.442 * * *$ & $-3.425 * * *$ & $0.392 * * *$ & $0.626 * * *$ \\
\hline & $(0.773)$ & $(0.111)$ & $(0.167)$ & $(0.740)$ & $(0.0867)$ & $(0.0766)$ \\
\hline \multirow[t]{2}{*}{ age } & $0.0425 * * *$ & $0.537 * * *$ & $0.155^{* * *}$ & & $-0.175^{* * * *}$ & \\
\hline & $(0.0149)$ & $(0.0428)$ & $(0.0489)$ & & $(0.0228)$ & \\
\hline \multirow[t]{2}{*}{ Other fractures } & $3.121 * * *$ & $-0.377 * * *$ & & & $1.036 * * *$ & \\
\hline & $(0.408)$ & $(0.136)$ & & & $(0.0582)$ & \\
\hline \multirow[t]{2}{*}{ emotional } & $3.421 * * *$ & $0.669 * * *$ & $4.103 * * *$ & & $1.629 * * *$ & $-0.219 * *$ \\
\hline & $(0.654)$ & $(0.101)$ & $(0.178)$ & & $(0.0653)$ & $(0.0893)$ \\
\hline \multirow[t]{2}{*}{ Rheumatoid } & $-6.340 * * *$ & $0.302 * * *$ & $-0.704 * * *$ & & & $-1.34 \mid * * *$ \\
\hline & $(0.909)$ & $(0.117)$ & $(0.14 I)$ & & & $(0.184)$ \\
\hline \multirow[t]{2}{*}{ Osteoarthritis } & $-4.212^{* * *}$ & & & $-10.93 * * *$ & $-0.242 * * *$ & \\
\hline & $(1.600)$ & & & $(1.349)$ & $(0.0574)$ & \\
\hline \multirow[t]{2}{*}{ Diabetes } & & $1.115^{* * * *}$ & $0.631 * * *$ & $3.679 * * *$ & $0.998 * * *$ & $0.727 * * *$ \\
\hline & & $(0.0872)$ & $(0.109)$ & $(0.689)$ & $(0.0588)$ & $(0.0646)$ \\
\hline \multirow[t]{2}{*}{ age2 } & & -0.00372 **** & $-0.0007 / 8^{* *}$ & $0.00202 * * *$ & $0.00149 * * *$ & $3.03 e-05^{*}$ \\
\hline & & $(0.000314)$ & $(0.000353)$ & $(0.000217)$ & $(0.000167)$ & $(1.72 \mathrm{e}-05)$ \\
\hline \multirow[t]{2}{*}{ lung } & & I.778**** & $1.902 * * *$ & $10.14 * * *$ & $1.053^{* * * *}$ & $1.387 * * *$ \\
\hline & & $(0.0937)$ & $(0.139)$ & $(1.6 \mid 3)$ & $(0.0665)$ & $(0.06 \mid 2)$ \\
\hline \multirow[t]{2}{*}{ Hip fracture } & & $0.662 * * *$ & $0.672 * * *$ & $2.072 * * *$ & $0.282^{* *}$ & $1.524 * * *$ \\
\hline & & $(0.171)$ & $(0.215)$ & $(0.70 \mathrm{I})$ & $(0.131)$ & $(0.0891)$ \\
\hline \multirow[t]{2}{*}{ Education years } & & $-0.101 * * *$ & $-0.266 * * *$ & & $-0.0250 * * *$ & \\
\hline & & $(0.00936)$ & $(0.0149)$ & & $(0.00657)$ & \\
\hline \multicolumn{7}{|l|}{ Constant } \\
\hline Observations & 156 & $\mathrm{I}, 472$ & $\mathrm{I}, 486$ & 96 & 4,510 & 1,930 \\
\hline
\end{tabular}

Standard errors in parentheses $* * * p<0.01, * * p<0.05, * p<0.1$ 
Appendix 6. (Continued)

\begin{tabular}{|c|c|c|c|c|c|c|c|c|}
\hline & Estonia & Spain & France & Italy & Luxemborg & Holland & Sweden & Slovenia \\
\hline \multicolumn{9}{|c|}{ Dependent variable: number of nights in hospital in the past 12 months } \\
\hline \multirow[t]{2}{*}{ male } & $-1.27 \mid * * *$ & $0.199 * * *$ & $-0.619 * *$ & $0.140 * * *$ & & & $0.0930 * *$ & $0.507 * * *$ \\
\hline & $(0.231)$ & $(0.0362)$ & $(0.247)$ & $(0.04 \mid 2)$ & & & $(0.0404)$ & $(0.0874)$ \\
\hline \multirow[t]{2}{*}{ hear } & $0.798 * * *$ & $0.301 * * *$ & $0.469 * *$ & $0.624 * * *$ & $3.544 * * *$ & $0.232 * * *$ & $0.393 * * * *$ & $0.566 * * *$ \\
\hline & $(0.228)$ & $(0.0385)$ & $(0.215)$ & $(0.0453)$ & $(0.356)$ & $(0.0482)$ & $(0.0429)$ & $(0.0952)$ \\
\hline \multirow[t]{2}{*}{ hypertension } & $0.592 * * *$ & & & $-0.152 * * *$ & $3.259 * * *$ & $0.174 * * *$ & $-0.626 * * *$ & $0.536 * * *$ \\
\hline & $(0.209)$ & & & $(0.0450)$ & $(0.358)$ & $(0.0484)$ & $(0.0443)$ & $(0.0921)$ \\
\hline \multirow[t]{2}{*}{ Heart attack } & & $0.575 * * *$ & $1.450 * * *$ & $0.790 * * *$ & $-0.923 * *$ & $0.669 * * *$ & $0.629 * * *$ & $1.523 * * *$ \\
\hline & & $(0.0429)$ & $(0.24 I)$ & $(0.0473)$ & $(0.438)$ & $(0.0524)$ & $(0.05 \mid 3)$ & $(0.0986)$ \\
\hline \multirow[t]{2}{*}{ stroke } & $3.136^{* * * *}$ & $0.828^{* * *}$ & & $1.207 * * *$ & $8.357^{* * * *}$ & $0.417^{* * * *}$ & $0.470 * * *$ & $-1.045^{* * *}$ \\
\hline & $(0.28 \mathrm{I})$ & $(0.0637)$ & & $(0.0588)$ & $(0.648)$ & $(0.0708)$ & $(0.0573)$ & $(0.222)$ \\
\hline \multirow[t]{2}{*}{ cataracts } & $1.308^{* * * *}$ & $0.150 * * *$ & $2.462 * * *$ & & $1.647 * * *$ & $-0.205^{* *}$ & $-0.615^{* * * *}$ & $-0.914^{* * *}$ \\
\hline & $(0.3 \mid 8)$ & $(0.0446)$ & $(0.274)$ & & $(0.488)$ & $(0.0828)$ & $(0.0609)$ & $(0.157)$ \\
\hline \multirow[t]{2}{*}{ choles } & $-0.679 * *$ & $-0.228 * * *$ & $-0.968 * * *$ & $-0.0816^{*}$ & $-0.904 * *$ & $0.407 * * *$ & $0.582 * * *$ & $-0.398 * * *$ \\
\hline & $(0.280)$ & $(0.0402)$ & $(0.286)$ & $(0.0494)$ & $(0.377)$ & $(0.0507)$ & $(0.0468)$ & $(0.105)$ \\
\hline \multirow[t]{2}{*}{ eyesight } & & $0.132 * * *$ & & $0.174 * * *$ & $-1.466 * * *$ & & & $0.725 * * *$ \\
\hline & & $(0.0382)$ & & $(0.0440)$ & $(0.524)$ & & & $(0.0870)$ \\
\hline \multirow[t]{2}{*}{ cancer } & $2.889 * * *$ & $0.882 * * *$ & $2.283 * * *$ & $1.225^{* * *}$ & $3.792 * * *$ & $0.575^{* * *}$ & $0.906 * * *$ & $2.275^{* * *}$ \\
\hline & $(0.389)$ & $(0.0489)$ & $(0.264)$ & $(0.0473)$ & $(0.426)$ & $(0.0585)$ & $(0.0476)$ & $(0.118)$ \\
\hline \multirow[t]{2}{*}{ stomach } & $-1.674 * * *$ & $0.265^{* * *}$ & $1.089 * * *$ & $-0.679 * * *$ & $1.470 *$ & $0.664 * * *$ & & $-1.616 * * *$ \\
\hline & $(0.455)$ & $(0.0628)$ & $(0.3 \mid 2)$ & $(0.128)$ & $(0.773)$ & $(0.08 \mid 4)$ & & $(0.21 \mathrm{I})$ \\
\hline \multirow[t]{2}{*}{ age } & & 0.0706 **** & 0.0498 *** & $0.333^{* * * *}$ & $0.0425^{* * *}$ & $0.0438 *$ & -0.143 *** & $0.560 * * *$ \\
\hline & & $(0.0185)$ & $(0.0 \mid I 2)$ & $(0.0208)$ & $(0.0149)$ & $(0.0263)$ & $(0.0197)$ & $(0.0670)$ \\
\hline \multirow[t]{2}{*}{ Other fractures } & I.334*** & $0.226 * * *$ & & $0.578 * * *$ & 3.121 *** & $0.263 * * *$ & & $0.833^{*} * *$ \\
\hline & $(0.36 I)$ & $(0.0494)$ & & $(0.0676)$ & $(0.408)$ & $(0.0624)$ & & $(0.120)$ \\
\hline \multirow[t]{2}{*}{ emotional } & $0.559 *$ & $0.169 * * *$ & $1.545 * * *$ & $0.609 * * *$ & $3.421 * * *$ & & I.278*** & $1.198 * * *$ \\
\hline & $(0.325)$ & $(0.0574)$ & $(0.295)$ & $(0.0677)$ & $(0.654)$ & & $(0.0594)$ & $(0.104)$ \\
\hline \multirow[t]{2}{*}{ Rheumatoid } & -1.536 **** & & & $-0.378 * * *$ & $-6.340 * * *$ & & $0.169 *$ & $1.499 * * *$ \\
\hline & $(0.444)$ & & & $(0.0782)$ & $(0.909)$ & & $(0.0962)$ & $(0.108)$ \\
\hline \multirow[t]{2}{*}{ Osteoarthritis } & $-2.964 * * * *$ & $0.245^{* * *}$ & $-1.152 * * *$ & & $-4.212^{* * * *}$ & $0.145^{* * *}$ & $-0.622 * * * *$ & $0.888^{*} * *$ \\
\hline & $(0.691)$ & $(0.0522)$ & $(0.273)$ & & $(1.600)$ & $(0.0501)$ & $(0.0593)$ & $(0.172)$ \\
\hline \multirow[t]{2}{*}{ Diabetes } & I.794*** & $0.386 * * *$ & $0.840 * * *$ & $0.256 * * *$ & & $0.615^{* * * *}$ & $1.342 * * *$ & $0.332 * * *$ \\
\hline & $(0.283)$ & $(0.0409)$ & $(0.260)$ & $(0.0509)$ & & $(0.0549)$ & $(0.0457)$ & $(0.108)$ \\
\hline \multirow[t]{2}{*}{ age2 } & $0.000177 * *$ & $-0.000317^{* *}$ & & $-0.00209 * * *$ & & $-0.000393^{* *}$ & $0.001 \mathrm{I} I * * *$ & $-0.00398 * * *$ \\
\hline & $(8.62 e-05)$ & $(0.000128)$ & & $(0.000 \mid 43)$ & & $(0.000193)$ & $(0.000 \mid 42)$ & $(0.000484)$ \\
\hline \multirow[t]{2}{*}{ lung } & I.378**** & $0.715^{* * *}$ & $2.496 * * *$ & $0.497 * * *$ & & $0.358 * * *$ & $0.557 * * * *$ & $0.614 * * *$ \\
\hline & $(0.306)$ & $(0.0491)$ & $(0.306)$ & $(0.0669)$ & & $(0.0550)$ & $(0.0694)$ & $(0.138)$ \\
\hline \multirow[t]{2}{*}{ Hip fracture } & & I.148*** & $2.766 * * *$ & $0.717 * * *$ & & $0.563^{* * * *}$ & $0.820 * * *$ & $0.48 I^{* *}$ \\
\hline & & $(0.0610)$ & $(0.403)$ & $(0.0827)$ & & $(0.0792)$ & $(0.0804)$ & $(0.228)$ \\
\hline \multirow[t]{2}{*}{ Education years } & -0.106 *** & $-0.0292 * * *$ & & $0.0400 * * *$ & & -0.0661 I*** & $-0.0740 * * *$ & $-0.0749 * * *$ \\
\hline & $(0.0317)$ & $(0.00390)$ & & $(0.00469)$ & & $(0.00660)$ & $(0.00549)$ & $(0.0133)$ \\
\hline \multirow[t]{2}{*}{ Constant } & & & & $-13.58 * * *$ & & & $4.696 * * *$ & \\
\hline & & & & $(0.752)$ & & & $(0.674)$ & \\
\hline Observations & 218 & 3,351 & 213 & 1,856 & 156 & $\mathrm{I}, 749$ & 2,597 & 984 \\
\hline
\end{tabular}

In Figure I, the blue line represents the trend over time in the number of academic papers located using a popular search engine in health sciences (PUBMED) using the search term "economic burden". 